\title{
Calibration of the U.S. Geological Survey National Crustal Model
}

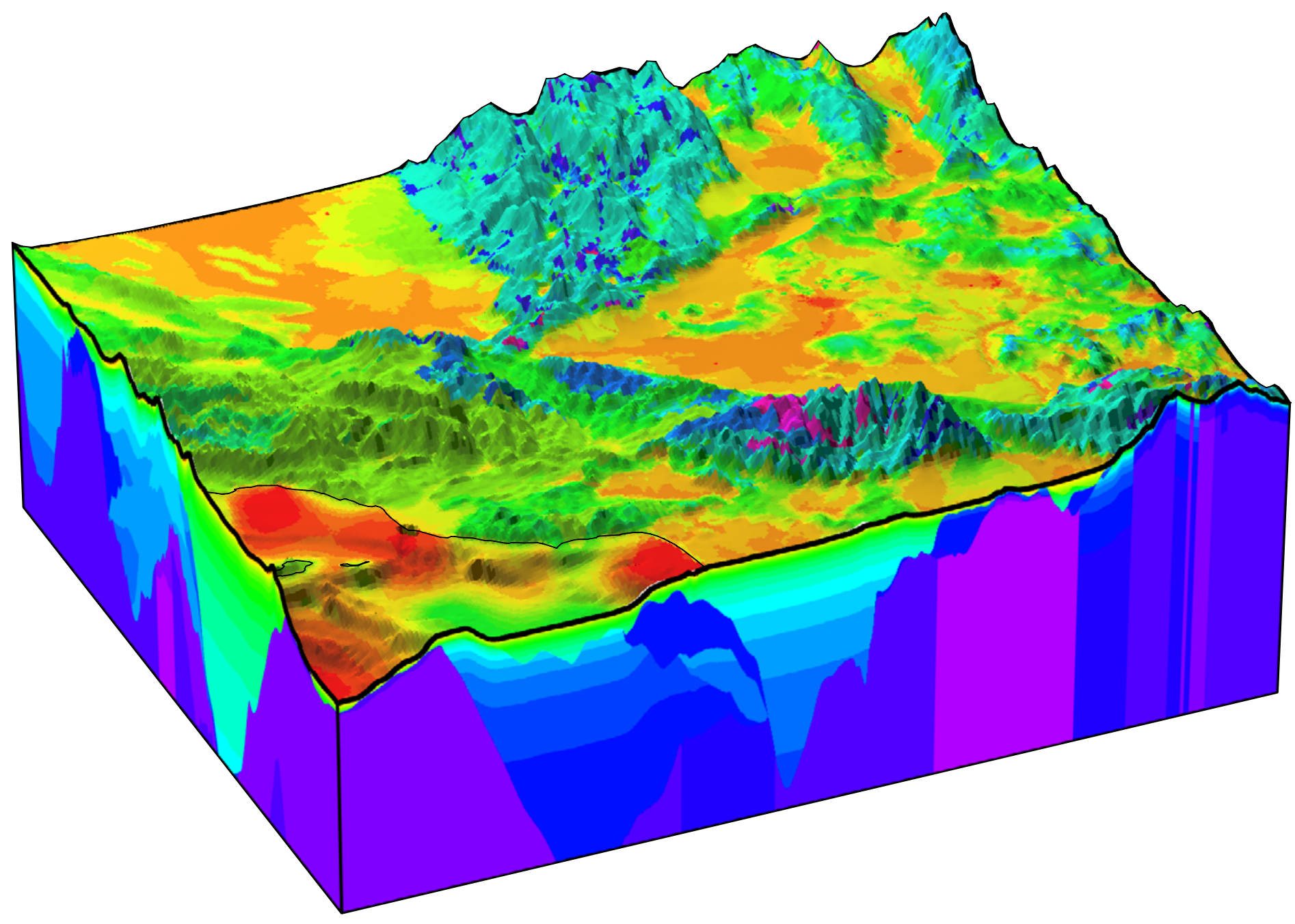

Open-File Report 2020-1052 
Cover. Shear-wave-velocity cross sections in southern California, from south to north, on the basis of the calibrations in this report and the related geologic framework. The time-averaged shear-wave velocity in the upper 30 meters is shown on top with a color scale that ranges between 100 and 1,000 meters per second. On the sides, shear-wave velocities extend to 10-kilometer depth with a vertical exaggeration of 10 times and have a color scale that ranges between 100 and 5,000 meters per second (Image created using calibrations in this report and the National Crustal Model geologic framework, v1.0.) 


\section{Calibration of the U.S. Geological Survey National Crustal Model}

By Oliver S. Boyd

Open-File Report 2020-1052 


\title{
U.S. Department of the Interior \\ DAVID BERNHARDT, Secretary
}

\author{
U.S. Geological Survey \\ James F. Reilly II, Director
}

U.S. Geological Survey, Reston, Virginia: 2020

For more information on the USGS - the Federal source for science about the Earth, its natural and living resources, natural hazards, and the environment—visit https://www.usgs.gov or call 1-888-ASK-USGS.

For an overview of USGS information products, including maps, imagery, and publications, visit https://store.usgs.gov/.

Any use of trade, firm, or product names is for descriptive purposes only and does not imply endorsement by the U.S. Government.

Although this information product, for the most part, is in the public domain, it also may contain copyrighted materials as noted in the text. Permission to reproduce copyrighted items must be secured from the copyright owner.

Suggested citation:

Boyd, 0.S., 2020, Calibration of the U.S. Geological Survey National Crustal Model: U.S. Geological Survey Open-File Report 2020-1052, 23 p., https://doi.org/10.3133/ofr20201052.

Associated data for this publication:

Boyd, 0.S., 2020a, Calibration coefficients for the U.S. Geological Survey National Crustal Model and depth to water table: U.S. Geological Survey data release, https://doi.org/10.5066/P9G03CP8.

ISSN 2331-1258 (online) 


\section{Acknowledgments}

I am grateful to the many colleagues and scientists that provided the information on which this work is based. Sean Ahdi at the University of Southern California, Domniki Asimaki at the California Institute of Technology, Albert Kottke at Pacific Gas and Electric, and Dave Boore, Tom Brocher, Walter Mooney, and Alan Yong at the U.S. Geological Survey provided critical velocity information. I appreciate Scott Callaghan and Phil Maechling at the Southern California Earthquake Center for their help to install and use their Unified Community Velocity Model software framework to extract velocity profiles from California models. I would also like to thank Bill Stephenson and Morgan Moschetti at the U.S. Geological Survey and Brandon Dugan at the Colorado School of Mines for their thorough reviews that significantly improved this report. This effort was funded by the U.S. Geological Survey Earthquake Hazards Program. 



\section{Contents}

Acknowledgments ……...................................................................................................................

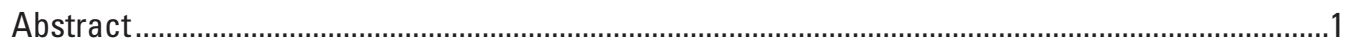

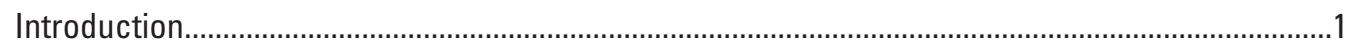

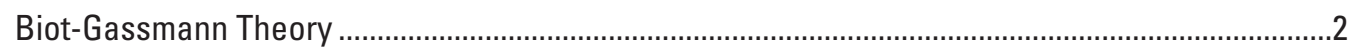

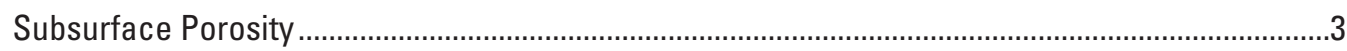

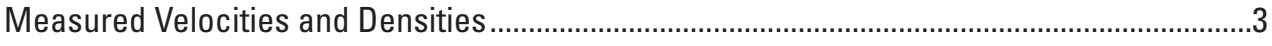

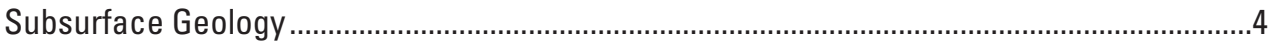

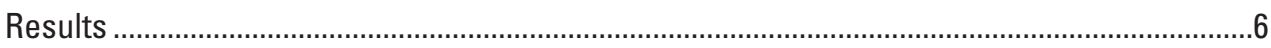

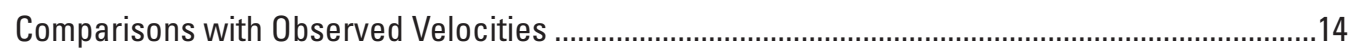

Water Table

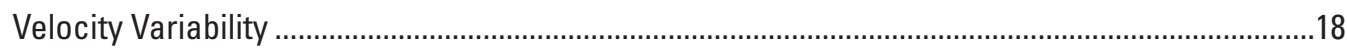

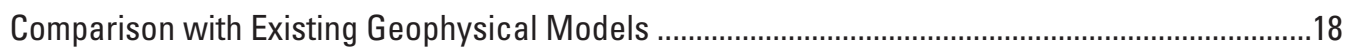

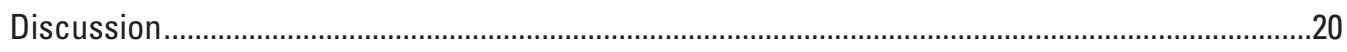

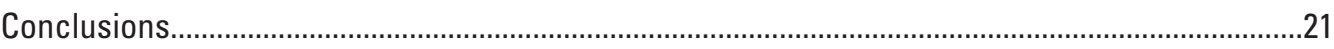

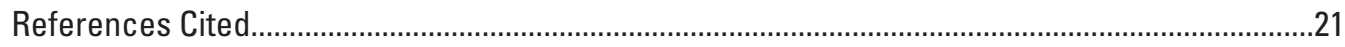

\section{Figures}

1. Map showing locations of geophysical profiles collected within the domain of the National Crustal Model...

2. Histograms of depths at which densities and compressional-wave and shear-wave velocities are measured

3. Plots of porosity versus normalized differential pressure - vertical stress minus pore pressure divided by surface pressure - and shear-wave velocity versus depth for sand, sandstone, and granodiorite.

4. Graph showing age versus estimates of $B$ for sedimentary and extrusive volcanic rock types.

5. Graphs showing the ratio of predicted relative to observed shear-wave velocity and compressional-wave velocity versus depth by using adjusted geologic profiles with spatially varying $B$ values.

6. Graph showing observed $V_{P} / V_{S}$ ratios versus depth as well as predicted relations for Quaternary sand, Late Cretaceous sandstone, and Mesozoic granodiorite with a water-table depth of 20 meters and 0 meters..

7. Map showing water-table depths across the National Crustal Model ............................17

8. Graphs showing shear-wave velocity, compressional-wave velocity, and density misfit comparisons for several regions from Vancouver, British Columbia, to southern California

\section{Tables}

1. Seismic velocity and density datasets collected across the United States...

2. Constants $A$ and $D$ for sedimentary and extrusive rocks (indexes 1 to 115) along with their standard deviations for equations 13 and 14

3. Constants $A$ and $D$ for intrusive and metamorphic rocks (indexes 116 to 115) along with their standard deviations for equations 13 and 14 


\section{Conversion Factors}

International System of Units to U.S. customary units

\begin{tabular}{lcl}
\hline \multicolumn{1}{c}{ Multiply } & By & \multicolumn{1}{c}{ To obtain } \\
\hline meter $(\mathrm{m})$ & Length & \\
kilometer $(\mathrm{km})$ & 3.281 & foot $(\mathrm{ft})$ \\
& 0.6214 & mile $(\mathrm{mi})$ \\
\hline meter per second $(\mathrm{m} / \mathrm{s})$ & Wave Speed & \\
kilometer per second $(\mathrm{km} / \mathrm{s})$ & 3.281 & foot per second $(\mathrm{ft} / \mathrm{s})$ \\
\hline & 3280.84 & feet per second $(\mathrm{ft} / \mathrm{s})$ \\
\hline kilogram per cubic $\mathrm{meter}\left(\mathrm{kg} / \mathrm{m}^{3}\right)$ & Density & \\
\hline & 0.06242 & pound per cubic foot $(\mathrm{lb} / \mathrm{ft} 3)$ \\
\hline pascal $\left(\mathrm{kg} / \mathrm{s}^{2} \mathrm{~m}\right)$ & Pressure & \\
\hline
\end{tabular}

\section{Datum}

Horizontal coordinate information is referenced to the North American Datum of 1983 (NAD 83).

\section{Abbreviations}

$\begin{array}{ll}\text { 3D } & \text { three dimensional } \\ \text { GMM } & \text { ground motion model } \\ \text { NCM } & \text { National Crustal Model } \\ \text { NCMGF } & \text { National Crustal Model geologic framework } \\ \text { NWIS } & \text { National Water Information System } \\ \text { USGS } & \text { U.S. Geological Survey } \\ V_{p} & \text { compressional-wave velocity } \\ V_{s} & \text { shear-wave velocity } \\ \text { WUS } & \text { western United States }\end{array}$




\title{
Calibration of the U.S. Geological Survey National Crustal Model
}

\author{
By Oliver S. Boyd
}

\section{Abstract}

The U.S. Geological Survey National Crustal Model (NCM) is being developed to include spatially varying estimates of site response in seismic hazard assessments. Primary outputs of the NCM are continuous velocity and density profiles from the Earth's surface to the mantle transition zone at 410-kilometer $(\mathrm{km})$ depth for each location on a 1-km grid across the conterminous United States. Datasets used to produce the NCM may have a resolution of better than $1 \mathrm{~km}$ near the Earth's surface in some regions, but, with increasing depth, NCM resolution decreases to tens to hundreds of kilometers in the mantle. Basic subsurface information is provided by the NCM geologic framework, thermal model, and petrologic and mineral physics database. In this report, the velocities and densities that can be extracted from the NCM are calibrated through the development of a porosity model based on Biot-Gassmann theory and more than 2,000 compressional- and (or) shear-wave velocity profiles less than $10 \mathrm{~km}$ deep from across the conterminous United States and southwestern Canada.

Sediment and rock porosities are derived from shear-wave velocity and are found to depend on effective pressure, rock type, and age (for sedimentary and extrusive volcanic deposits). Porosity-effective pressure functions are then estimated for each rock type (and age for sedimentary and extrusive volcanic deposits). Unconsolidated sediments are found to have higher porosities than consolidated units, which have higher porosities than unweathered igneous units; young sedimentary units (for example, Quaternary age units) tend to have higher porosities than older sedimentary units (for example, pre-Cenozoic age units); porosity decreases with increasing effective pressure; and porosities can decrease quickly through the weathered layer of intrusive rocks.

Comparing two Los Angeles area velocity models and the U.S. Geological Survey Bay Area velocity model with the NCM, the NCM does a better job on average of reproducing observed shear-wave velocities below $1 \mathrm{~km}$ per second because it has less bias and uncertainty. Approaching and above $1 \mathrm{~km}$ per second, the NCM tends to underpredict observed shear-wave velocity. Whereas several factors could contribute to this, the primary factor is probably bias in the NCM geologic framework. For example, the NCM will predict lower velocities in places where the depth to bedrock and basement appear shallower in the measured velocity profiles than specified in the NCM geologic framework. With regard to observed compressional-wave velocity and density, the NCM has significantly less bias than California models for the former, especially below $2 \mathrm{~km}$ per second, and all models tend to overpredict density for densities less than about 2,200 kilograms per cubic meter.

\section{Introduction}

Seismic hazards and associated risks are present in many regions across the United States. Large historic earthquakes have occurred along the San Andreas Fault, within the New Madrid seismic zone, in the Puget Lowland, outside of Charleston, South Carolina, and near Washington, D.C. These events, coupled with seismically vulnerable structures built before modern building codes, particularly in the central and eastern United States, lead to appreciable risk from earthquakes. A major factor in assessing seismic hazards is the ground motion produced by an earthquake, which is strongly influenced by the subsurface geology. For example, because of differences in mechanical properties, ground composed of poorly consolidated sediments typically undergoes shaking of greater intensity than ground composed of bedrock such as granite or sandstone. Ground shaking within sedimentary basins may be of greater duration and amplitude relative to locations outside of these basins because of mechanical properties and wave focusing. Knowledge of the surface and subsurface geologic variations can be used to constrain, interpolate, and extrapolate geophysical data and create a model of the three-dimensional (3D) geophysical structure across the United States.

A U.S. Geological Survey (USGS) National Crustal Model (NCM) is being developed to assist with earthquake-hazard estimates in the USGS National Seismic Hazard Model by supporting estimates of ground shaking in response to an earthquake. Improved hazard assessments may also be used for planning and risk assessments but are not intended for site-specific engineering applications. The NCM is composed of geophysical attribute-depth profiles on a 1-kilometer $(\mathrm{km})$ grid from which metrics can be extracted for 
ground motion models (GMMs). Because of their application in the western United States (WUS) GMMs, the time-averaged shear-wave velocities in the upper 30 meters $(\mathrm{m}$; termed $\left.V_{S 30}\right)$ and the depths to 1.0 and 2.5 kilometers $/$ second $(\mathrm{km} / \mathrm{s})$ shear-wave velocities (termed $Z_{1.0}$ and $Z_{2.5}$ ) are parameters of immediate interest. The NCM has the flexibility to provide additional metrics such as fundamental frequency, a fully frequency-dependent site-response function derived from one-dimensional, two-dimensional, or 3D analyses, or 3D geophysical volumes for wavefield simulations. The NCM may also benefit other aspects of seismic hazard analysis through better accounting for path-dependent attenuation, path-dependent geometric spreading, and more accurate estimation of earthquake-source properties such as hypocentral location, magnitude, focal mechanism, and stress drop.

Each geophysical profile within the NCM is based on subsurface geology, porosity, effective and total stress, temperature, and mineral- and rock-physics theory. The primary elements used to construct the NCM are: (1) 3D geologic framework (Boyd, 2019), (2) petrologic and mineral physics database (Sowers and Boyd, 2019), (3) 3D temperature model (Boyd, 2020b), (4) calibration of a porosity model for the estimation of bulk rock density and seismic velocity (this report), and (5) validation. These elements make use of a host of geology, borehole, gravity, and seismic datasets to connect subsurface geological variability with geophysical attributes and seismic response.

Seismic velocities within the NCM are determined using Biot-Gassmann theory (Lee, 2010), in which the elastic moduli of geologic units are determined by porosity, saturation, the bulk modulus of air and water, and the elastic moduli of the solid-rock matrix. The NCM seismic velocity profiles are calibrated by estimating how quickly porosity decreases with depth for each geologic unit within the NCM geologic framework (NCMGF) by using measured velocity and density profiles across the United States. The resulting calibration coefficients and supplementary information are available in the associated data release (Boyd, 2020a), and codes to produce geophysical attribute profiles are available at the NCM code repository at https://code.usgs.gov/ghsc/ $\mathrm{nshmp} / \mathrm{ncm} /$.

\section{Biot-Gassmann Theory}

To model the velocity and density of a porous material as a function of depth, Biot-Gassmann theory as presented by Lee (2010) is used in which porosity, $\phi$, plays a vital role.

The compressional-wave velocity $V_{P}$ and shear-wave velocity $V_{S}$ through a composite material denoted by the subscript $b$ is given by

$$
V_{P}=\sqrt{\frac{k_{b}+4 \mu_{b} / 3}{\rho_{b}}} \text { and }
$$

$$
V_{S}=\sqrt{\frac{\mu_{b}}{\rho_{b}}}
$$

which are a function of bulk density, $\rho_{b}$, and bulk and shear moduli, $k_{b}$ and $\mu_{b}$. The density is a linear combination of the density of the solid-rock matrix, denoted in the following by the subscript lowercase $s$; the density of material within the pore space, denoted by the subscripts $w$ and $a$ for the densities of water and air:

$$
\rho_{b}=\rho_{s}(1-\phi)+S \rho_{w} \phi+(1-S) \rho_{a} \phi,
$$

and where $S$ is the fraction of pore space saturated with water.

The bulk and shear moduli are functions of the moduli of the solid-rock matrix, again denoted by the subscript lowercase $s$; the average bulk modulus, denoted by the subscript $a v$; and the Biot coefficients $\beta_{P}$ and $\beta_{S}$; and are given by

$$
\begin{gathered}
k_{b}=k_{S}\left(1-\beta_{P}\right)+\beta_{P} k_{a v} \text { and } \\
\mu_{b}=\mu_{s}\left(1-\beta_{S}\right) .
\end{gathered}
$$

The average bulk modulus is determined from the average compressibility given by

$$
\frac{1}{k_{a v}}=\frac{\beta_{P}-\phi_{N}}{k_{s}}+\frac{\phi_{N}}{k_{w, a}}
$$

and a Voigt (1928) average, dependent on saturation, is chosen for the effective modulus of the pore space, $k_{w, a}$, which essentially is based on the assumption of patchy saturation (Mavko and Mukerji, 1998). The Biot coefficients are

$$
\begin{gathered}
\beta_{P}=\frac{\phi_{N}(1+\alpha)}{1+\alpha \phi_{N}} \text { and } \\
\beta_{S}=\frac{\phi_{N}(1+\gamma \alpha)}{1+\gamma \alpha \phi_{N}} .
\end{gathered}
$$

The average compressibility and Biot coefficients differ from Lee's original presentation in that the porosities are normalized by a maximum porosity

$$
\phi_{N} \equiv \frac{\phi}{\phi_{\max }}
$$

which is defined so that at the surface, the maximum porosity, $\phi_{\max }$, corresponds to the condition where the pressure of water within the pore space is equal to and increases at the same rate as the solid-rock-matrix pressure. This modification accommodates the modeling of very low observed shear-wave velocities (less than $100 \mathrm{~m} / \mathrm{s}$ ). Without this modification, these low velocities would require very high porosities so that pore pressure would be greater and increase faster than the solid-rock-matrix pressure, leading to steadily increasing porosity with depth. Applying a maximum porosity and using 
it to normalize the porosity in equations 7 and 8 prevents this condition. At the maximum porosity, the shear modulus of the aggregate material is zero, and the bulk modulus is the average defined by equation 6 . Typically, this maximum porosity is about 70 to 80 percent, depending on the density of the minerals that make up the rock matrix.

This maximum porosity, where pore space is saturated with water, is a lower bound. If saturated with air, the maximum porosity would be closer to 1 , and a transition between the two would depend on the depth to the water table and saturation. For simplicity, the lower value of maximum porosity is chosen.

The parameters $\gamma$ and $\alpha$ in the Biot coefficients, where the latter is referred to as the consolidation parameter, control the Biot coefficients' sensitivity to pressure. The former, $\gamma$, is also a function of $\alpha$ and is given by

$$
\gamma=\frac{(1+m \alpha)}{1+\alpha}
$$

where $m$ and $\alpha$ account for differential pressure, $\Delta P$, which represents the rock's vertical stress minus its pore pressure. These parameters, with $\Delta P$ given in megaPascals, are specified by

$$
\begin{gathered}
m=M_{1} \triangle P M_{E} \text { and } \\
\alpha=A_{1} \Delta P A_{E},
\end{gathered}
$$

where $\alpha$ is not allowed to rise above a constant $A_{2}$, and $m$ is not allowed to fall below another constant $M_{2}$. Several of these constants differ from those presented in Lee (2010) because of the use of normalized porosity in equations 6 through 8. Simultaneous grid-search fitting of the porosity, compressional-wave velocity, and shear-wave velocity in saturated sands near the Gulf of Mexico from Zimmer (2003), which was used in the analysis of Lee (2010), yields constants $M_{1}, A_{1}$, and $A_{2}$ equal to 10,30 , and 11 , respectively. The constant $M_{2}$ equal to 2 , and exponents $M_{E}$ equal to -0.6 and $A_{E}$ equal to -0.4 , were retained from Lee (2010). From a chi-squared analysis of residuals, $M_{1}, M_{E}$, and $A_{2}$ are found to have natural $\log \left(\log _{e}\right)$ standard deviations of $0.16,0.21$, and 0.14 , respectively. The parameters $M_{2}, A_{E}$, and $A_{l}$ have nearly one-sided chi-squared distributions so that these parameters are likely to be less than 3.4 , greater than 21 , and greater than -0.55 (mean plus or minus one standard deviation in $\log _{e}$ space), respectively. These values were determined for saturated sands, and how they may vary according to lithology is unknown. The resulting NCM shear-wave velocity model, however, will not depend on the choice of constants because observed shear-wave velocities are used to derive lithology-dependent porosity-depth relations, which are then used to calculate the shear-wave velocities in the model. NCM bulk density and compressional-wave velocities will, however, be sensitive to variations in these constants and the resulting porosity relations.

A functional form for porosity is assumed in which porosity cannot be equal to or less than 0 nor equal to or greater than 1, and the differential pressure normalized by surface pressure is not equal to or less than 0 . These assumptions result in the following equation:

$$
\log (-\log (\phi))=A \log \left(\Delta P_{N}\right)^{0.5}+B,
$$

where the constants $A$ and $B$ are functions of rock type and age (explained further in the "Subsurface Porosity" section). The exponent 0.5 in this equation was chosen after visual inspection of the estimates of porosity versus pressure that are shown in the "Results" section. Although conceivably this exponent also depends on rock type and age, for simplicity and to guard against overfitting limited data, no attempt was made to include this dependence.

\section{Subsurface Porosity}

Equations 2, 3, 5, 8, 10, 11, and 12 are combined and rearranged to solve for porosity as a function of shear-wave velocity, differential pressure, and shear modulus and density of the solid-rock matrix and pore-space material. Moduli and density of the solid-rock matrix are estimated by applying mineral physics information from the NCM Petrologic and Mineral Physics Database (Sowers and Boyd, 2019) to geologic profiles from the NCMGF (Boyd, 2019) that are adjusted by eye at each measurement location. Calibration proceeds by estimating $A$ and $B$ in equation 13 by using a robust linear least-squares regression for each rock type and age within the NCMGF and separately at each measurement location. The latter is done to allow for the spatial variability of $B$ for a given lithology. The coefficients $A$ and $B$ are further refined to ensure that the resulting porosity-pressure relationships reproduce the observed shear-wave velocities.

A more direct approach would be to estimate porosity as a function of bulk density (by rearranging the variables in eq. 3); however, the quantity of primary interest for seismic hazard studies is shear-wave velocity. Developing a porosity model derived from shear-wave velocities will ensure that when that model is applied, shear-wave velocities will be estimated with minimal bias. Although measurements of shallow-depth density are few and no collocated density and shear-wave-velocity measurements have been made, additional analysis is warranted.

\section{Measured Velocities and Densities}

Seismic velocity and density profiles and $V_{S 30}$ values at 6,791 distinct locations across the United States were gathered from several existing studies (table 1; fig. 1), and 
modest improvements and simplifications were made. For example, the database compiled by Ahdi and others (2017) is composed solely of shear-wave-velocity profiles reported to depths of $70 \mathrm{~m}$, but many of the underlying studies included shear-wave-velocity profiles that extend to depths of several thousand meters as well as compressional-wave velocities. This additional information is included here. Regarding simplification, if profiles are specified as a series of constant-velocity layers, the velocity is assigned as a single value to the middle of the layer.

Shallow to moderately deep ( $0-10 \mathrm{~km}$ depth) shear-wave-velocity profiles were used to calculate and calibrate the porosity model, whereas measured compressional-wave velocities were compared with predicted velocities to better understand how well the underlying Biot-Gassmann theory is working and under what conditions it should be modified. Improvements to analyses may be gained by using the following: the USGS $V_{S 30}$ database (Yong and others, 2016); velocity profiles from Mooney (2013), which tend to have few samples in the upper few kilometers but extend deep into the mantle; and density profiles. In all, nearly 30,000 shear-wave-velocity observations extending from the surface to a depth of almost $10 \mathrm{~km}$ (fig. 2) were used for calibration.

\section{Subsurface Geology}

Lithologic profiles, which include multiple rock units of varying age and petrology, were used to calculate the solid-rock-matrix moduli and density (subscript lowercase $s$ in eqs. 3,4 , and 5) as well as to estimate the values of the constants $A$ and $B$, which depend on rock type and age, in the porosity function (eq. 13). These profiles were extracted from the NCMGF at each shear-wave velocity-measurement location. The mineralogy for each rock type and the methods used to calculate mineral moduli and density are specified in the NCM petrologic and mineral physics database (Sowers and Boyd, 2019). The depths of geologic contacts within these profiles are iteratively adjusted to reflect observed velocity variations and refined lithology-dependent $A$ and $B$ values. In some cases, the lithology and geologic contacts that are noted in geologic logs (see for example, Gibbs and others [1992]) can be correlated with mapped surface geology and contacts within the NCMGF. Although these geologic logs were considered, contacts were typically inferred from changes in seismic velocity and similarity to inferred lithology-dependent, porosity-effective pressure relationships.

This effort yields obvious problems with the NCMGF as noted in its associated documentation. One limitation of the NCMGF is that units that are not present at the surface cannot be propagated into the subsurface. This is seen, for example, in the Georgia Basin at the border of Washington and British Columbia, where the Miocene to Pliocene Boundary Bay Formation, which consists primarily of sandstone and mudstone (Mustard and Rouse, 1994), underlies unconsolidated Quaternary sediments. The Boundary Bay Formation is not present in the geologic map compilation of Garrity and Soller (2009). In this case, Miocene sandstone has been inserted into an updated version of the NCMGF in this region. In another example from the valleys near Salt Lake City, Utah, semiconsolidated glaciolacustrine deposits beneath unconsolidated sediment and mud (Stephenson and others, 2012) are missing from the NCMGF in much of the region because of very few nearby outcrops. Here, a late Pliocene medium-grained, mixed-clastic rock, as observed in these nearby outcrops, has been inserted into an updated version of the NCMGF.

Table 1. Seismic velocity and density datasets collected across the United States.

$\left[V_{B}\right.$ compressional-wave velocity; $V_{S}$, shear-wave velocity; $\rho$, density; $V_{S 30}$, time-averaged shear-wave velocity to 30 -meters depth]

\begin{tabular}{llcc}
\hline \multicolumn{1}{c}{ Dataset } & \multicolumn{1}{c}{ Region } & $\begin{array}{c}\text { Number of } \\
\text { profiles }\end{array}$ & Type \\
\hline Boore (2003) & California, Oregon, and Washington & 277 & $V_{B} V_{S}$ \\
Shi and Asimaki (2018) & California, Oregon, and Washington & 176 & $V_{S}$ \\
Brocher and others (1998), Brocher (2005a) & California & 114 & $V_{B} \rho$ \\
Brocher and Horta (1998) & Oregon & 9 & $V_{B} \rho$ \\
Brocher and Ruebel (1998) & Washington & 22 & $V_{B} \rho$ \\
Ahdi and others (2017) & California, Oregon, Washington, and southwestern Canada & 996 & $V_{B} V_{S}$ \\
Kohler and others (2003) & Los Angeles, California & 367 & $V_{B} V_{S}$ \\
Magistrale and others (2008) & Wasatch Front, Utah & 229 & $V_{B} V_{S}$ \\
Kansas Geological Survey (2017) & Kansas & 117 & $V_{B} \rho$ \\
Hashash and others (2014) & Central and eastern United States & 58 & $V_{B} V_{S}$ \\
Yong and others (2016) & Conterminous United States & 2,763 & $V_{S 30}$ \\
Mooney (2013) & North America east of longitude 115 ${ }^{\circ} \mathrm{W}$ & 2,603 & $V_{B} V_{S}$ \\
\hline
\end{tabular}




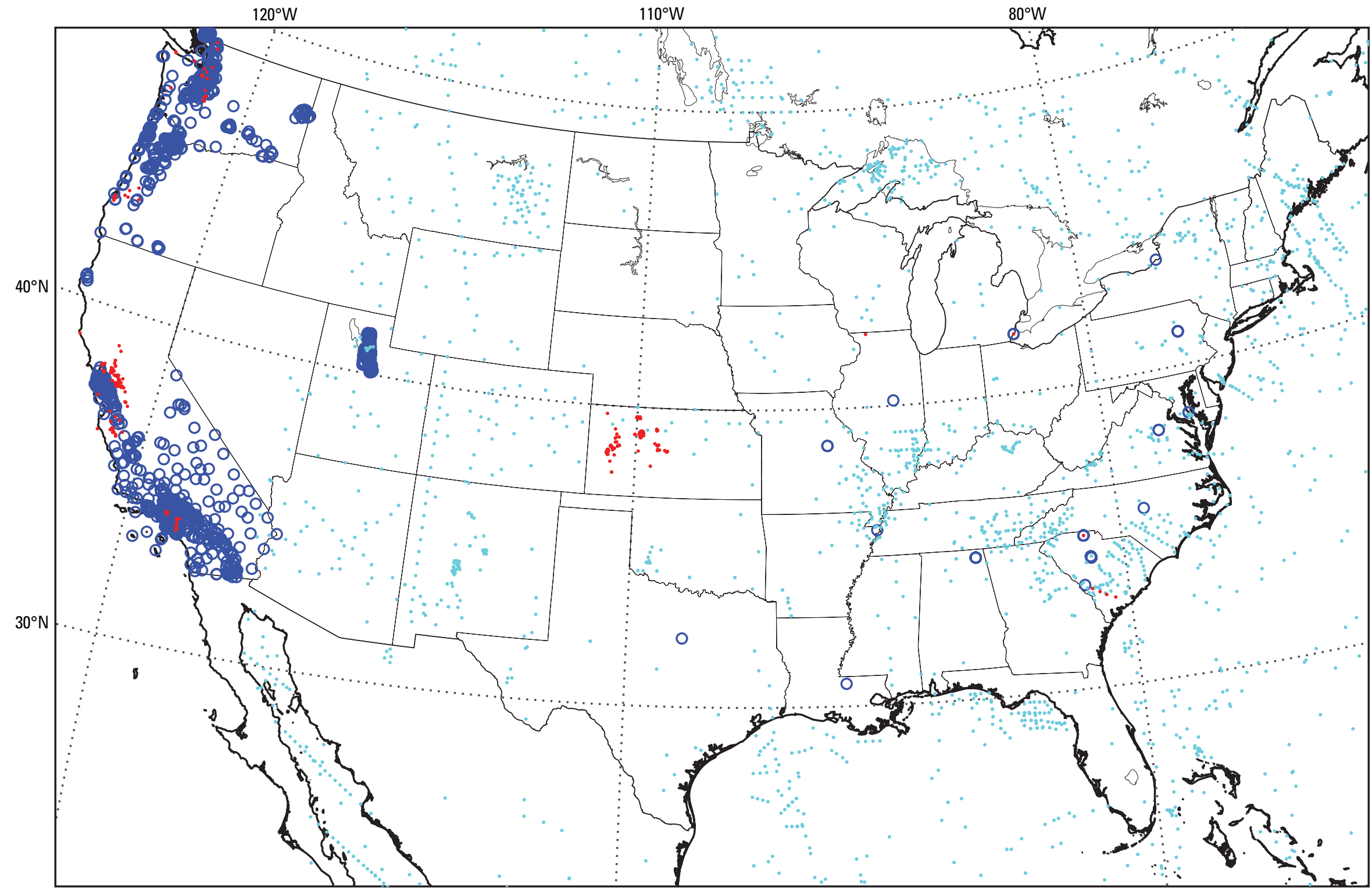

Figure 1. Locations of geophysical profiles collected within the domain of the National Crustal Model. Blue circles are shear-wave and, in some cases, compressional-wave velocity profiles; red dots are compressional-wave velocity and density profiles; and cyan dots are deep (tens to hundreds of kilometers; modified from Mooney, 2013) shear-wave and compressional-wave-velocity profiles. 


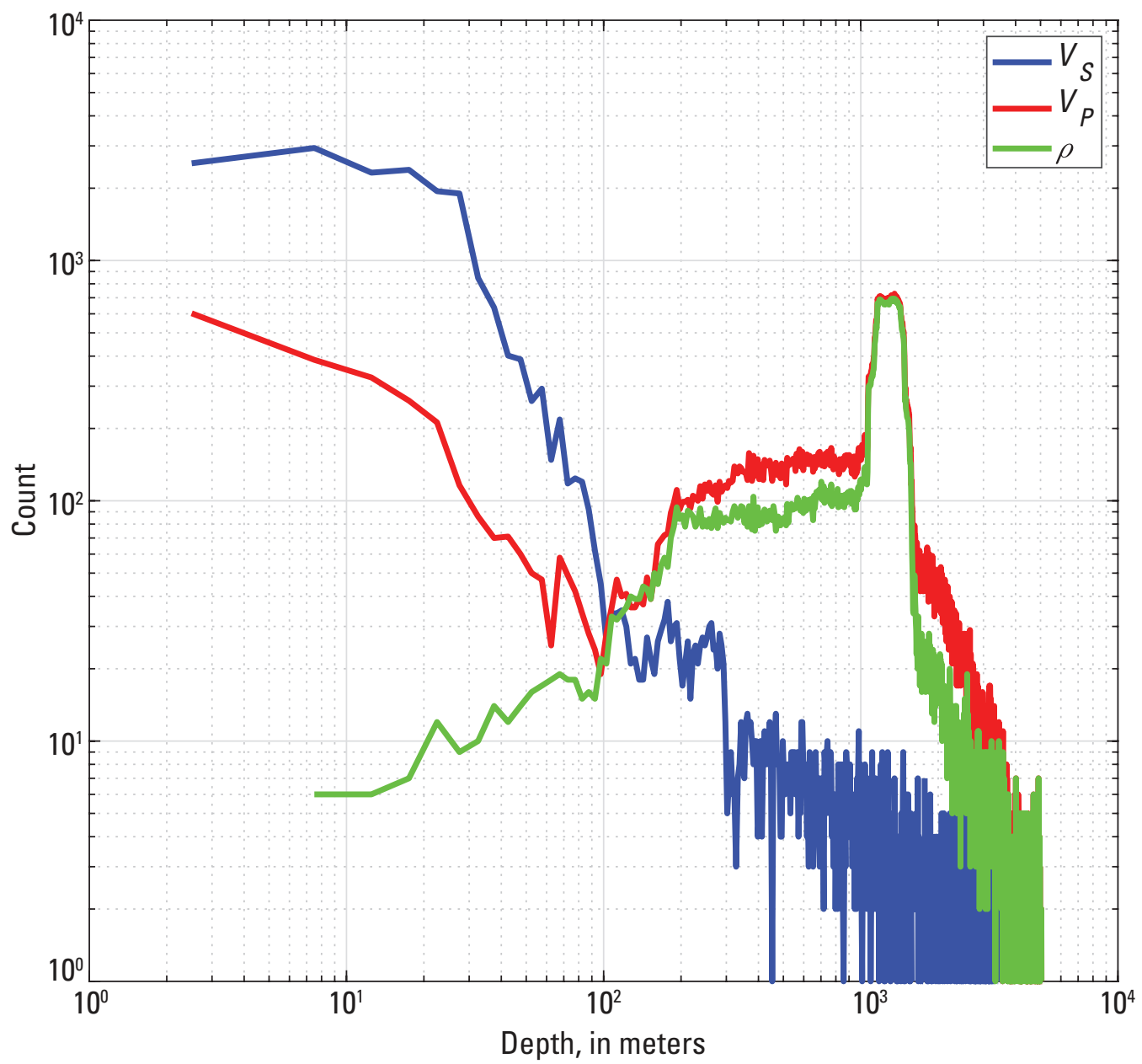

Figure 2. Histograms of depths at which densities and compressional-wave and shear-wave velocities are measured, not including Mooney's (2013) compilation. Histogram bin widths are 5 meters depth. ( $V_{S}$, shear-wave velocity; $V_{P}$, compressional-wave velocity; $\rho$, density)

\section{Results}

A total of 162 unique lithology-age combinations from 57 rock types are available for analysis (table 2 and 3). Rock types from granite and basalt to sandstone and limestone to unconsolidated sediment span ages from Proterozoic to Holocene. Examples for three rock types showing porosity versus differential pressure normalized by surface pressure and shear-wave velocity versus depth are shown in figure 3 .

As expected, porosity decreases with increasing differential pressure or depth and is greatest for unconsolidated rock types. Lithified sedimentary units have a large range in porosity from nearly 0 to almost 40 percent at $100-\mathrm{m}$ depth, and intrusive igneous units generally have moderate porosity that decreases quickly with depth to less than 5 percent below the weathered zone, which is, in most cases, less than $100 \mathrm{~m}$ thick. When separated by rock type and age, large ranges in $A$ and $B$ (eq. 13) result. For simplicity, a single average slope, $A$, is estimated for each rock type, and in the first iteration, the intercept, $B$, is estimated independently for each rock type and age. Intercepts for sedimentary and extrusive volcanic rock types are found to increase with age (because porosities decrease) as shown in figure 4 according to

$$
B=C A g e^{0.25}+D,
$$

where Age is in millions of years, and $D$ is a constant dependent on rock type. The exponent 0.25 is subjectively chosen from visual inspection to linearize estimates of $B$ versus Age. The constant $C$ has been found to be $0.29 \pm$ 0.12 , which is used for rock indexes 1 through 115 . A single average value of $B$ is used for intrusive and metamorphic rock types, which have indexes 116 through 209. Values for $A, B$, and $D$ along with their uncertainties are given in table 2 and 3 .

Several rock types are not represented, or their porosities have been estimated only once or twice on the basis of few observations. In these cases, their slopes are assigned on the 
Table 2. Constants $A$ and $D$ for sedimentary and extrusive rocks (indexes 1 to 115 ) along with their standard deviations for equations 13 and 14 , which are needed to calculate porosity and geophysical attributes for each geologic unit. The columns $\mathrm{N} V_{S} 0 \mathrm{bs}$ and $\mathrm{N} V_{S}$ Prof provide the total number of data points and profiles, respectively, in which each unit appears. Blank cells indicate that the rock type did not have data with which to estimate uncertainty. Please see the ScienceBase data release associated with this report (Boyd, 2020a) for an accessible version of the most up-to-date coefficients.

$\left[A\right.$, slope relating porosity and pressure in equation $13 ; \sigma_{A}$, standard deviation of $A ; D$, intercept in equation $14 ; \sigma_{D}$, standard deviation of $\left.D\right]$

\begin{tabular}{|c|c|c|c|c|c|c|c|}
\hline Index & Rock type & $\mathrm{N} V_{s}$ Obs & $\mathrm{N} V_{s}$ Prof & $A$ (unitless) & $\sigma_{A}$ & $D$ (unitless) & $\sigma_{D}$ \\
\hline 1 & Unconsolidated material & 6,299 & 347 & 0.44 & 0.006 & -0.98 & 0.008 \\
\hline 2 & Alluvium & 1,656 & 358 & 0.54 & 0.018 & -0.89 & 0.018 \\
\hline 3 & Silt & 106 & 11 & 0.43 & 0.045 & -1.07 & 0.043 \\
\hline 4 & Sand & 231 & 44 & 0.49 & 0.029 & -1.12 & 0.029 \\
\hline 5 & Floodplain & 0 & 0 & 0.54 & & -0.89 & \\
\hline 6 & Gravel & 73 & 12 & 0.63 & 0.097 & -0.45 & 0.112 \\
\hline 7 & Levee & 0 & 0 & 0.44 & & -0.98 & \\
\hline 8 & Delta & 0 & 0 & 0.54 & & -0.89 & \\
\hline 9 & Alluvial fan & 0 & 0 & 0.54 & & -0.89 & \\
\hline 10 & Alluvial terrace & 0 & 0 & 0.54 & & -0.89 & \\
\hline 11 & Lake or marine sediment & 646 & 99 & 0.48 & 0.019 & -1.17 & 0.020 \\
\hline 12 & Playa & 0 & 0 & 0.48 & & -1.17 & \\
\hline 13 & Mud flat & 0 & 0 & 0.48 & & -1.17 & \\
\hline 14 & Beach sand & 0 & 0 & 0.49 & & -1.12 & \\
\hline 15 & Terrace & 0 & 0 & 0.49 & & -1.12 & \\
\hline 16 & Eolian & 0 & 0 & 0.49 & & -1.12 & \\
\hline 17 & Dune sand & 0 & 0 & 0.49 & & -1.12 & \\
\hline 18 & Sand sheet & 0 & 0 & 0.49 & & -1.12 & \\
\hline 19 & Loess & 0 & 0 & 0.49 & & -1.12 & \\
\hline 20 & Volcanic ash & 0 & 0 & 0.49 & & -1.12 & \\
\hline 21 & Mass-wasting material & 0 & 0 & 0.63 & & -0.45 & \\
\hline 22 & Colluvium & 0 & 0 & 0.63 & & -0.45 & \\
\hline 23 & Mudflow & 0 & 0 & 0.46 & & -1.01 & \\
\hline 24 & Lahar & 0 & 0 & 0.63 & & -0.45 & \\
\hline 25 & Debris flow & 0 & 0 & 0.63 & & -0.45 & \\
\hline 26 & Landslide & 0 & 0 & 0.63 & & -0.45 & \\
\hline 27 & Talus & 0 & 0 & 0.63 & & -0.45 & \\
\hline 28 & Glacial drift & 1,407 & 194 & 0.44 & 0.014 & -0.60 & 0.020 \\
\hline 29 & Till & 11 & 2 & 0.83 & 0.150 & -0.79 & 0.222 \\
\hline 30 & Moraine & 0 & 0 & 0.44 & & -0.60 & \\
\hline 31 & Stratified glacial sediment & 0 & 0 & 0.44 & & -0.60 & \\
\hline 32 & Glacial outwash sediment & 0 & 0 & 0.44 & & -0.60 & \\
\hline 33 & Outwash & 0 & 0 & 0.44 & & -0.60 & \\
\hline 34 & Sub-/supra-glacial sediment & 0 & 0 & 0.44 & & -0.60 & \\
\hline 35 & Glaciolacustrine & 0 & 0 & 0.44 & & -0.60 & \\
\hline 36 & Glacial-marine sediment & 0 & 0 & 0.46 & & -0.06 & \\
\hline
\end{tabular}


Table 2. Constants $A$ and $D$ for sedimentary and extrusive rocks (indexes 1 to 115 ) along with their standard deviations for equations 13 and 14 , which are needed to calculate porosity and geophysical attributes for each geologic unit. The columns $N V_{S} 0$ bs and $\mathrm{N} V_{S}$ Prof provide the total number of data points and profiles, respectively, in which each unit appears. Blank cells indicate that the rock type did not have data with which to estimate uncertainty. Please see the ScienceBase data release associated with this report (Boyd, 2020a) for an accessible version of the most up-to-date coefficients.-Continued

$\left[A\right.$, slope relating porosity and pressure in equation $13 ; \sigma_{A}$, standard deviation of $A ; D$, intercept in equation $14 ; \sigma_{D}$, standard deviation of $\left.D\right]$

\begin{tabular}{|c|c|c|c|c|c|c|c|}
\hline Index & Rock type & $\mathrm{N} V_{s}$ Obs & $\mathrm{N} V_{s}$ Prof & $A$ (unitless) & $\sigma_{A}$ & $D$ (unitless) & $\sigma_{D}$ \\
\hline 37 & Biogenic material & 0 & 0 & 0.37 & & -0.72 & \\
\hline 38 & Peat & 9 & 1 & 0.37 & 0.157 & -0.72 & 0.107 \\
\hline 39 & Coral & 0 & 0 & 0.70 & & -0.39 & \\
\hline 40 & Residuum & 402 & 23 & 2.05 & 0.154 & -2.76 & 0.166 \\
\hline 41 & Clay or mud & 2,860 & 215 & 0.46 & 0.008 & -1.01 & 0.010 \\
\hline 42 & Sedimentary rock & 0 & 0 & 0.43 & & -0.69 & \\
\hline 43 & Clastic rock & 0 & 0 & 0.42 & & -0.48 & \\
\hline 44 & Mudstone & 133 & 42 & 0.49 & 0.066 & -0.94 & 0.076 \\
\hline 45 & Claystone & 12 & 1 & 0.39 & 1.279 & -0.78 & 3.316 \\
\hline 46 & Bentonite & 0 & 0 & 0.39 & & -0.78 & \\
\hline 47 & Shale & 84 & 9 & 0.39 & 0.042 & -0.64 & 0.053 \\
\hline 48 & Black shale & 62 & 8 & 0.39 & 0.116 & -0.91 & 0.140 \\
\hline 49 & Oil shale & 0 & 0 & 0.39 & & -0.91 & \\
\hline 50 & Argillite & 130 & 20 & 0.62 & 0.066 & -1.25 & 0.083 \\
\hline 51 & Siltstone & 118 & 33 & 0.45 & 0.072 & -0.63 & 0.080 \\
\hline 52 & Fine-grained mixed clastic rock & 0 & 0 & 0.42 & & -0.48 & \\
\hline 53 & Sandstone & 3,862 & 706 & 0.49 & 0.007 & -0.91 & 0.010 \\
\hline 54 & Arenite & 0 & 0 & 0.49 & & -0.91 & \\
\hline 55 & Orthoquartzite & 22 & 2 & 0.37 & 0.098 & -0.88 & 0.110 \\
\hline 56 & Calcarenite & 0 & 0 & 0.70 & & -0.39 & \\
\hline 57 & Arkose & 238 & 30 & 0.25 & 0.057 & -0.34 & 0.068 \\
\hline 58 & Wacke & 0 & 0 & 0.29 & & -0.47 & \\
\hline 59 & Graywacke & 94 & 10 & 0.29 & 0.076 & -0.47 & 0.093 \\
\hline 60 & Medium-grained mixed clastic rock & 708 & 116 & 0.42 & 0.032 & -0.48 & 0.036 \\
\hline 61 & Conglomerate & 482 & 79 & 0.69 & 0.050 & -1.07 & 0.117 \\
\hline 62 & Sedimentary breccia & 5 & 1 & 0.42 & 0.336 & -0.81 & 0.360 \\
\hline 63 & Coarse-grained mixed clastic rock & 0 & 0 & 0.42 & & -0.48 & \\
\hline 64 & Olistostrome & 0 & 0 & 0.49 & & -0.94 & \\
\hline 65 & Melange & 27 & 6 & 0.57 & 0.194 & -0.65 & 0.211 \\
\hline 66 & Carbonate rock & 0 & 0 & 0.70 & & -0.39 & \\
\hline 67 & Limestone & 1,201 & 22 & 0.70 & 0.061 & -0.39 & 0.092 \\
\hline 68 & Dolostone & 366 & 4 & 0.01 & 0.065 & 0.10 & 0.117 \\
\hline 69 & Mixed carbonate/clastic rock & 0 & 0 & 0.56 & & 0.01 & \\
\hline 70 & Mixed volcanic/clastic rock & 0 & 0 & 0.49 & & -0.24 & \\
\hline 71 & Phosphorite & 0 & 0 & 0.43 & & -0.69 & \\
\hline 72 & Chemical sedimentary rock & 0 & 0 & 0.43 & & -0.69 & \\
\hline
\end{tabular}


Table 2. Constants $A$ and $D$ for sedimentary and extrusive rocks (indexes 1 to 115 ) along with their standard deviations for equations 13 and 14 , which are needed to calculate porosity and geophysical attributes for each geologic unit. The columns $\mathrm{N} V_{S} \mathrm{Obs}$ and $\mathrm{N} V_{S}$ Prof provide the total number of data points and profiles, respectively, in which each unit appears. Blank cells indicate that the rock type did not have data with which to estimate uncertainty. Please see the ScienceBase data release associated with this report (Boyd, 2020a) for an accessible version of the most up-to-date coefficients.-Continued

$\left[A\right.$, slope relating porosity and pressure in equation $13 ; \sigma_{A}$, standard deviation of $A ; D$, intercept in equation $14 ; \sigma_{D}$, standard deviation of $\left.D\right]$

\begin{tabular}{|c|c|c|c|c|c|c|c|}
\hline Index & Rock type & $\mathrm{N} V_{s}$ Obs & $\mathrm{N} V_{s}$ Prof & $A$ (unitless) & $\sigma_{A}$ & $D$ (unitless) & $\sigma_{D}$ \\
\hline 73 & Evaporite & 0 & 0 & 0.43 & & -0.69 & \\
\hline 74 & Chert & 0 & 0 & 0.43 & & -0.69 & \\
\hline 75 & Novaculite & 0 & 0 & 0.43 & & -0.69 & \\
\hline 76 & Iron formation & 0 & 0 & 0.43 & & -0.69 & \\
\hline 77 & Exhalite & 0 & 0 & 0.43 & & -0.69 & \\
\hline 78 & Coal & 0 & 0 & 0.43 & & -0.69 & \\
\hline 79 & Mixed coal/clastic rock & 0 & 0 & 0.43 & & -0.69 & \\
\hline 80 & Volcanic rock & 0 & 0 & 0.56 & & -0.90 & \\
\hline 81 & Glassy volcanic rock & 0 & 0 & 0.56 & & -0.90 & \\
\hline 82 & Obsidian & 0 & 0 & 0.56 & & -0.90 & \\
\hline 83 & Vitrophyre & 0 & 0 & 0.56 & & -0.90 & \\
\hline 84 & Pumice & 0 & 0 & 0.56 & & -0.90 & \\
\hline 85 & Pyroclastic rock & 0 & 0 & 0.56 & & -0.90 & \\
\hline 86 & Tuff & 0 & 0 & 0.56 & & -0.90 & \\
\hline 87 & Welded tuff & 0 & 0 & 0.56 & & -0.90 & \\
\hline 88 & Ash-flow tuff & 0 & 0 & 0.56 & & -0.90 & \\
\hline 89 & Ignimbrite & 0 & 0 & 0.56 & & -0.90 & \\
\hline 90 & Volcanic breccia & 0 & 0 & 0.56 & & -0.90 & \\
\hline 91 & Lava flow & 0 & 0 & 0.56 & & -0.90 & \\
\hline 92 & Bimodal suite & 0 & 0 & 0.56 & & -0.90 & \\
\hline 93 & Felsic volcanic rock & 12 & 2 & 0.57 & 0.262 & -0.53 & 0.203 \\
\hline 94 & Alkali-feldspar rhyolite & 0 & 0 & 0.57 & & -0.76 & \\
\hline 95 & Rhyolite & 72 & 14 & 0.57 & 0.102 & -0.76 & 0.099 \\
\hline 96 & Rhyodacite & 0 & 0 & 0.57 & & -0.76 & \\
\hline 97 & Dacite & 0 & 0 & 0.57 & & -0.76 & \\
\hline 98 & Alkali-feldspar trachyte & 0 & 0 & 0.48 & & -0.84 & \\
\hline 99 & Trachyte & 0 & 0 & 0.48 & & -0.84 & \\
\hline 100 & Quartz latite & 0 & 0 & 0.48 & & -0.84 & \\
\hline 101 & Latite & 33 & 9 & 0.48 & 0.082 & -0.84 & 0.101 \\
\hline 102 & Intermediate volcanic rock & 62 & 18 & 0.48 & 1.322 & -1.03 & 3.359 \\
\hline 103 & Trachyandesite & 0 & 0 & 0.43 & & -0.73 & \\
\hline 104 & Andesite & 187 & 24 & 0.43 & 0.064 & -0.73 & 0.079 \\
\hline 105 & Mafic rock & 45 & 5 & 0.68 & 0.105 & -1.05 & 0.124 \\
\hline 106 & Trachybasalt & 0 & 0 & 0.68 & & -1.34 & \\
\hline 107 & Basalt & 670 & 94 & 0.68 & 0.036 & -1.34 & 0.040 \\
\hline 108 & Tholeiite & 0 & 0 & 0.68 & & -1.34 & \\
\hline
\end{tabular}


Table 2. Constants $A$ and $D$ for sedimentary and extrusive rocks (indexes 1 to 115 ) along with their standard deviations for equations 13 and 14 , which are needed to calculate porosity and geophysical attributes for each geologic unit. The columns $\mathrm{N} V_{S} 0 \mathrm{bs}$ and $\mathrm{N} V_{S}$ Prof provide the total number of data points and profiles, respectively, in which each unit appears. Blank cells indicate that the rock type did not have data with which to estimate uncertainty. Please see the ScienceBase data release associated with this report (Boyd, 2020a) for an accessible version of the most up-to-date coefficients.-Continued

$\left[A\right.$, slope relating porosity and pressure in equation $13 ; \sigma_{A}$, standard deviation of $A ; D$, intercept in equation $14 ; \sigma_{D}$, standard deviation of $\left.D\right]$

\begin{tabular}{|c|c|c|c|c|c|c|c|}
\hline Index & Rock type & $\mathrm{N} V_{s}$ Obs & N $V_{S}$ Prof & $A$ (unitless) & $\sigma_{A}$ & $D$ (unitless) & $\sigma_{D}$ \\
\hline 109 & Hawaiite & 0 & 0 & 0.68 & & -1.34 & \\
\hline 110 & Alkaline basalt & 0 & 0 & 0.68 & & -1.34 & \\
\hline 111 & Alkalic volcanic rock & 0 & 0 & 0.68 & & -1.34 & \\
\hline 112 & Phonolite & 0 & 0 & 0.68 & & -1.34 & \\
\hline 113 & Tephrite & 0 & 0 & 0.68 & & -1.34 & \\
\hline 114 & Ultramafitite & 0 & 0 & 0.68 & & -1.34 & \\
\hline 115 & Volcanic carbonatite & 0 & 0 & 0.68 & & -1.34 & \\
\hline
\end{tabular}

Table 3. Constants $A$ and $B$ for intrusive and metamorphic rocks (indexes 116 to 209) along with their standard deviations for equation 13 , which is needed to calculate porosity and geophysical attributes for each geologic unit. The columns $\mathrm{N} V_{S} \mathrm{Obs}$ and $\mathrm{N} V_{S}$ Prof provide the total number of data points and profiles, respectively, in which each unit appears. Blank cells indicate that the rock type did not have data with which to estimate uncertainty. Please see the ScienceBase data release associated with this report (Boyd, 2020a) for an accessible version of the most up-to-date coefficients.

$\left[A\right.$, slope relating porosity and pressure in equation $13 ; \sigma_{A}$, standard deviation of $A ; B$, intercept in equation $14 ; \sigma_{B}$, standard deviation of $\left.B\right]$

\begin{tabular}{|c|c|c|c|c|c|c|c|}
\hline Index & Rock type & $\mathrm{N} v_{s}$ Obs & $N V_{s}$ Prof & $A$ (unitless) & $\sigma_{A}$ & $B$ (unitless) & $\sigma_{B}$ \\
\hline 116 & Plutonic rock & 0 & 0 & 0.74 & & 0.00 & \\
\hline 117 & Aplite & 0 & 0 & 0.87 & & 0.06 & \\
\hline 118 & Porphyry & 0 & 0 & 0.87 & & 0.06 & \\
\hline 119 & Lamprophyre & 0 & 0 & 0.87 & & 0.06 & \\
\hline 120 & Pegmatite & 0 & 0 & 0.87 & & 0.06 & \\
\hline 121 & Granitoid & 40 & 9 & 0.87 & 0.154 & 0.06 & 0.166 \\
\hline 122 & Charnockite & 0 & 0 & 0.87 & & 0.06 & \\
\hline 123 & Alkali-feldspar granite & 0 & 0 & 0.87 & & 0.06 & \\
\hline 124 & Quartz monzodiorite & 0 & 0 & 0.87 & & -0.32 & \\
\hline 125 & Monzodiorite & 0 & 0 & 0.87 & & -0.32 & \\
\hline 126 & Quartz diorite & 9 & 2 & 0.87 & 0.401 & -0.32 & 0.426 \\
\hline 127 & Diorite & 3 & 1 & 0.87 & 0.599 & -0.20 & 0.764 \\
\hline 128 & Diabase & 0 & 0 & 0.77 & & -0.27 & \\
\hline 129 & Granite & 139 & 34 & 0.77 & 0.096 & -0.27 & 0.110 \\
\hline 130 & Peraluminous granite & 0 & 0 & 0.77 & & -0.27 & \\
\hline 131 & Metaluminous granite & 0 & 0 & 0.77 & & -0.27 & \\
\hline 132 & Subaluminous granite & 0 & 0 & 0.77 & & -0.27 & \\
\hline 133 & Peralkaline granite & 0 & 0 & 0.77 & & -0.27 & \\
\hline 134 & Granodiorite & 378 & 77 & 0.87 & 0.060 & -0.19 & 0.067 \\
\hline 135 & Tonalite & 50 & 10 & 1.01 & 0.141 & -0.29 & 0.162 \\
\hline 136 & Trondhjemite & 0 & 0 & 1.01 & & -0.29 & \\
\hline 137 & Alkali-feldspar syenite & 0 & 0 & 0.77 & & -0.27 & \\
\hline
\end{tabular}


Table 3. Constants $A$ and $B$ for intrusive and metamorphic rocks (indexes 116 to 209) along with their standard deviations for equation 13 , which is needed to calculate porosity and geophysical attributes for each geologic unit. The columns $\mathrm{N} V_{S} 0 \mathrm{bs}$ and $\mathrm{N} V_{S}$ Prof provide the total number of data points and profiles, respectively, in which each unit appears. Blank cells indicate that the rock type did not have data with which to estimate uncertainty. Please see the ScienceBase data release associated with this report (Boyd, 2020a) for an accessible version of the most up-to-date coefficients.-Continued

$\left[A\right.$, slope relating porosity and pressure in equation $13 ; \sigma_{A}$, standard deviation of $A ; B$, intercept in equation $14 ; \sigma_{B}$, standard deviation of $\left.B\right]$

\begin{tabular}{|c|c|c|c|c|c|c|c|}
\hline Index & Rock type & $\mathrm{N} V_{s}$ Obs & $\mathbf{N} V_{s}$ Prof & $A$ (unitless) & $\sigma_{A}$ & $B$ (unitless) & $\sigma_{B}$ \\
\hline 138 & Quartz syenite & 0 & 0 & 0.77 & & -0.27 & \\
\hline 139 & Syenite & 0 & 0 & 0.77 & & -0.27 & \\
\hline 141 & Monzonite & 0 & 0 & 0.47 & & 0.48 & \\
\hline 142 & Gabbroid & 0 & 0 & 0.47 & & 0.20 & \\
\hline 144 & Monzogabbro & 0 & 0 & 0.47 & & 0.20 & \\
\hline 145 & Quartz gabbro & 0 & 0 & 0.47 & & 0.20 & \\
\hline 146 & Gabbro & 4 & 2 & 0.47 & 0.451 & 0.20 & 0.478 \\
\hline 147 & Norite & 0 & 0 & 0.47 & & 0.20 & \\
\hline 148 & Troctolite & 0 & 0 & 0.47 & & 0.20 & \\
\hline 152 & Ultramafic intrusive rock & 11 & 1 & 0.47 & 0.248 & 0.53 & 0.268 \\
\hline 153 & Peridotite & 0 & 0 & 0.47 & & 0.53 & \\
\hline 154 & Dunite & 0 & 0 & 0.47 & & 0.53 & \\
\hline 155 & Kimberlite & 0 & 0 & 0.47 & & 0.53 & \\
\hline 156 & Pyroxenite & 0 & 0 & 0.47 & & 0.53 & \\
\hline 157 & Hornblendite & 0 & 0 & 0.47 & & 0.53 & \\
\hline 158 & Intrusive carbonatite & 0 & 0 & 0.47 & & 0.53 & \\
\hline 159 & Metamorphic rock & 0 & 0 & 0.56 & & 0.38 & \\
\hline 166 & Metasedimentary rock & 69 & 18 & 0.61 & 0.126 & 0.23 & 0.163 \\
\hline 167 & Meta-argillite & 0 & 0 & 0.56 & & 0.38 & \\
\hline 168 & Slate & 0 & 0 & 0.56 & & 0.38 & \\
\hline 169 & Quartzite & 0 & 0 & 0.56 & & 0.38 & \\
\hline 170 & Metaconglomerate & 0 & 0 & 0.56 & & 0.38 & \\
\hline 171 & Marble & 0 & 0 & 0.56 & & 0.38 & \\
\hline 172 & Metavolcanic rock & 64 & 6 & 0.13 & 0.177 & 1.61 & 0.189 \\
\hline 173 & Felsic metavolcanic rock & 1,556 & 18 & 0.02 & 0.016 & 1.50 & 0.029 \\
\hline 174 & Metarhyolite & 0 & 0 & 0.02 & & 1.50 & \\
\hline 175 & Keratophyre & 0 & 0 & 0.48 & & 0.09 & \\
\hline 176 & Intermediate metavolcanic rock & 0 & 1 & 0.48 & & 0.09 & \\
\hline 177 & Mafic metavolcanic rock & 0 & 0 & 0.47 & & 0.20 & \\
\hline
\end{tabular}


Table 3. Constants $A$ and $B$ for intrusive and metamorphic rocks (indexes 116 to 209) along with their standard deviations for equation 13 , which is needed to calculate porosity and geophysical attributes for each geologic unit. The columns $\mathrm{N} V_{S} 0 \mathrm{bs}$ and $\mathrm{N} V_{S}$ Prof provide the total number of data points and profiles, respectively, in which each unit appears. Blank cells indicate that the rock type did not have data with which to estimate uncertainty. Please see the ScienceBase data release associated with this report (Boyd, 2020a) for an accessible version of the most up-to-date coefficients.-Continued

$\left[A\right.$, slope relating porosity and pressure in equation $13 ; \sigma_{A}$, standard deviation of $A ; B$, intercept in equation $14 ; \sigma_{B}$, standard deviation of $\left.B\right]$

\begin{tabular}{|c|c|c|c|c|c|c|c|}
\hline Index & Rock type & $\mathrm{N} V_{s}$ Obs & $\mathrm{N} V_{s}$ Prof & $A$ (unitless) & $\sigma_{A}$ & $B$ (unitless) & $\sigma_{B}$ \\
\hline 178 & Metabasalt & 0 & 0 & 0.68 & & -0.22 & \\
\hline 179 & Spilite & 0 & 0 & 0.68 & & -0.22 & \\
\hline 180 & Greenstone & 19 & 4 & 0.59 & 0.355 & -0.15 & 0.368 \\
\hline 181 & Phyllite & 3 & 3 & 0.59 & 1.816 & 0.52 & 2.152 \\
\hline 182 & Schist & 47 & 14 & 0.59 & 0.107 & 0.48 & 0.121 \\
\hline 183 & Greenschist & 0 & 0 & 0.59 & & 0.48 & \\
\hline 184 & Blueschist & 0 & 0 & 0.59 & & 0.48 & \\
\hline 185 & Mica schist & 216 & 56 & 0.38 & 0.049 & -0.02 & 0.058 \\
\hline 186 & Biotite schist & 0 & 0 & 0.38 & & -0.02 & \\
\hline 187 & Pelitic schist & 7 & 1 & 1.35 & 0.187 & -0.78 & 0.211 \\
\hline 188 & Quartz-feldspar schist & 0 & 0 & 1.35 & & -0.78 & \\
\hline 189 & Calc-silicate schist & 0 & 0 & 1.35 & & -0.78 & \\
\hline 190 & Amphibole schist & 0 & 0 & 1.35 & & -0.78 & \\
\hline 191 & Granofels & 0 & 0 & 0.56 & & 0.38 & \\
\hline 192 & Gneiss & 55 & 9 & 0.70 & 0.114 & -0.17 & 0.124 \\
\hline 193 & Felsic gneiss & 0 & 0 & 0.70 & & -0.17 & \\
\hline 194 & Granitic gneiss & 0 & 0 & 0.70 & & -0.17 & \\
\hline 195 & Biotite gneiss & 0 & 0 & 0.70 & & -0.17 & \\
\hline 196 & Mafic gneiss & 0 & 0 & 0.70 & & -0.17 & \\
\hline 197 & Orthogneiss & 57 & 14 & 1.05 & 0.147 & -0.37 & 0.162 \\
\hline 198 & Paragneiss & 0 & 0 & 0.38 & & -0.02 & \\
\hline 199 & Migmatite & 0 & 0 & 0.56 & & 0.38 & \\
\hline 200 & Amphibolite & 96 & 2 & 0.26 & 0.082 & 1.33 & 0.122 \\
\hline 201 & Granulite & 0 & 0 & 0.26 & & 1.33 & \\
\hline 202 & Tectonite & 0 & 0 & 0.26 & & 1.33 & \\
\hline 203 & Tectonic melange & 0 & 0 & 0.26 & & 1.33 & \\
\hline 204 & Tectonic breccia & 0 & 0 & 0.26 & & 1.33 & \\
\hline 205 & Cataclasite & 0 & 0 & 0.26 & & 1.33 & \\
\hline 206 & Phyllonite & 0 & 0 & 0.26 & & 1.33 & \\
\hline 207 & Mylonite & 0 & 0 & 0.26 & & 1.33 & \\
\hline 208 & Flaser gneiss & 0 & 0 & 0.70 & & -0.17 & \\
\hline 209 & Augen gneiss & 0 & 0 & 0.70 & & -0.17 & \\
\hline
\end{tabular}

Figure 3 (following page). Plots of porosity versus normalized differential pressure-vertical stress minus pore pressure divided by surface pressure - (left) and shear-wave velocity versus depth (right) for sand (top), sandstone (middle), and granodiorite (bottom). Different colors correspond to different ages and represent non-overlapping binned mean values. Black dots are individual data points for that geologic unit, and gray dots represent all available data. Lines are fits assuming a single average slope and $B$ value that follows equation 14; and the dashed line at the top is the porosity-pressure limit imposed for any given profile. For clarity, note that only 2 of the 19 available sandstone ages are shown. (m, meter; $\mathrm{m} / \mathrm{s}$, meter per second) 

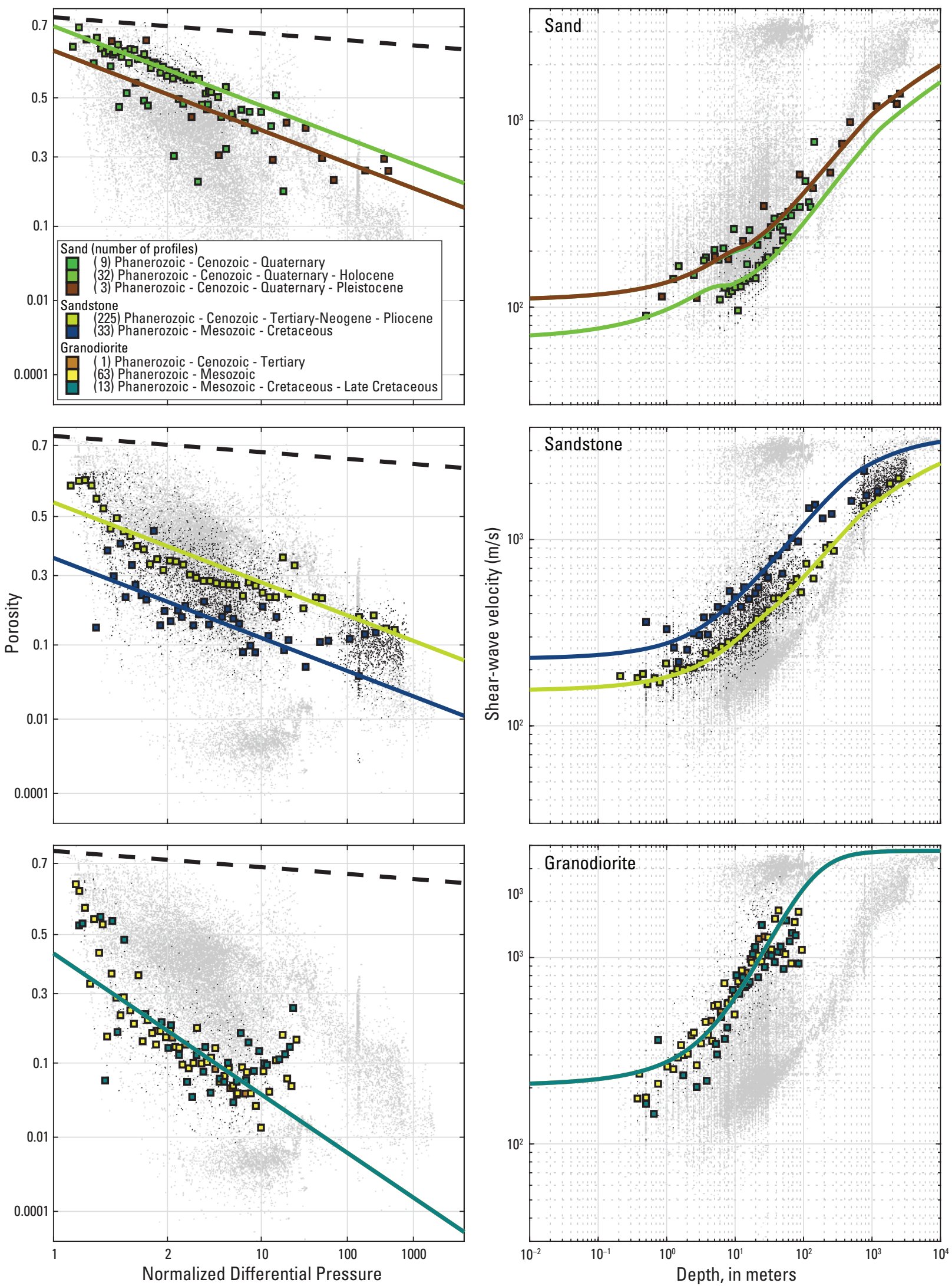


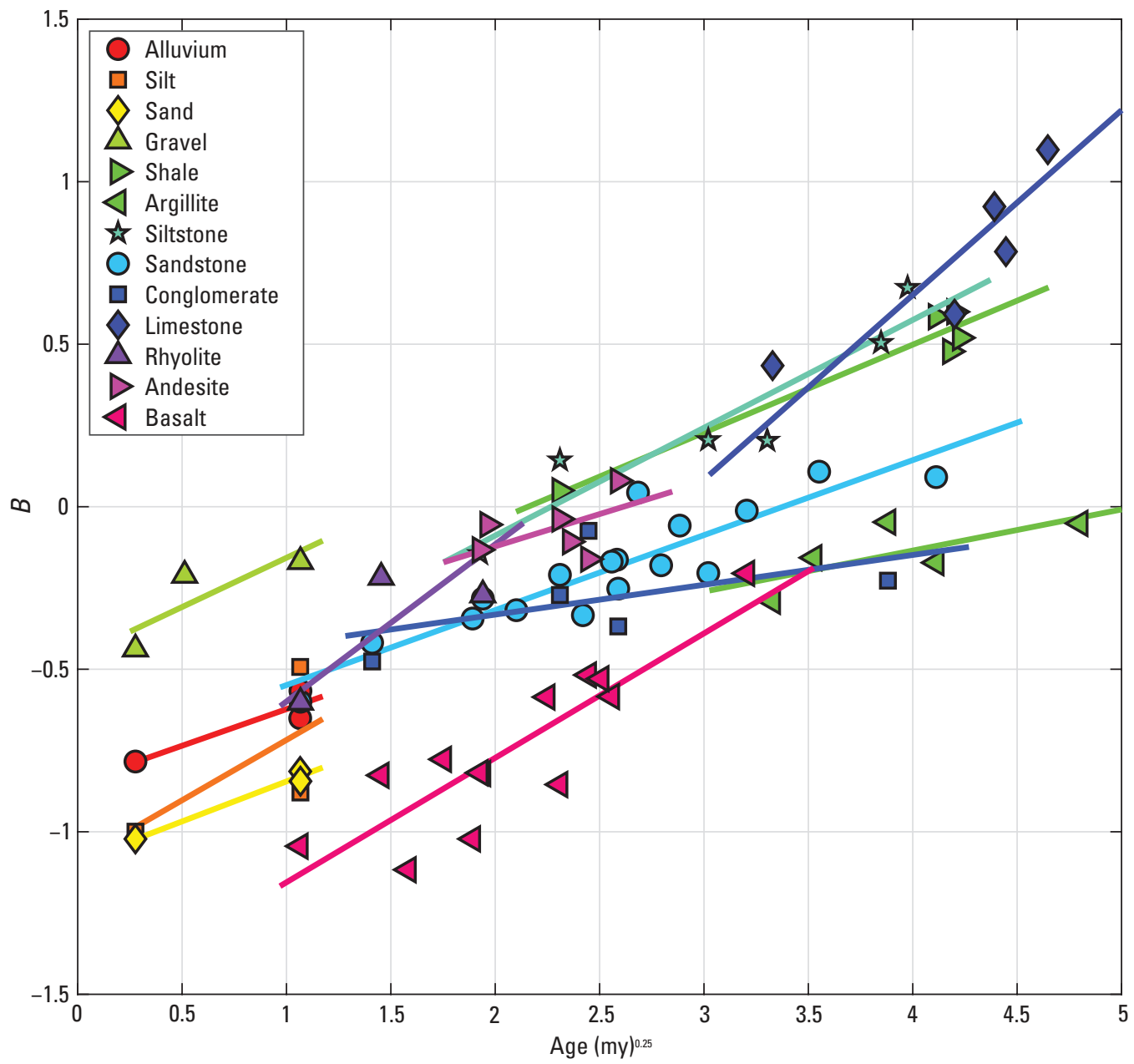

Figure 4. Age versus estimates of $B$ for sedimentary and extrusive volcanic rock types. (my, million years)

basis of materials with similar compositions. For more general rock types such as sedimentary and plutonic, which are not explicitly represented in the calibration dataset, averages of the sedimentary and plutonic rock types, respectively, are used.

Whereas decreasing porosity with depth in unconsolidated and sedimentary units can be considered partially the result of compaction during sedimentation, much of the porosity in shallow igneous rocks is due to weathering. As a result, predicting near-surface velocities is problematic if the thickness of this weathering layer is unknown. Pelletier and others (2016) have produced a model of the global surface at 1-km resolution depicting the thickness of weathered rock, but it has not yet been implemented in the NCMGF.

\section{Comparisons with Observed Velocities}

Sites having observations of both shear-wave and compressional-wave velocities are used to assess the underlying Biot-Gassmann theory. In figure 5, predictions of shear-wave and compressional-wave velocities based on the adjusted geologic profiles and spatially varying $B$ values are shown relative to observations. Whereas the scatterplots do not indicate an apparent bias with depth, the histograms reveal that the underlying Biot-Gassmann theory could use some minor modifications, particularly with respect to the parameters $\beta_{P}$ (eq. 7) and $\gamma$ (eq. 10), in order to better match observations.

Lee (2005) suggested that above the water table, when saturation is less than 100 percent, $\gamma$ should be equal to 1 . This condition on $\gamma$ causes a significant and sudden jump (more than $200 \mathrm{~m} / \mathrm{s}$ ) in the calculated shear-wave velocity above the water table that is rarely observed in the velocity profiles. Alternatively, $\gamma$ could be defined as a function of saturation, decreasing to 1 at zero saturation; but here, too, a substantial increase in shear-wave velocity is produced that is not generally observed. In most cases, the shear-wave velocity continues to decrease above the water table, consistent with no change to how $\gamma$ is formulated. Therefore, equation 10 is maintained above the water table.

The other modification is made to the $\beta_{P}$ function. In the standard formulation of this function (eq. 7), compressional-wave velocities above the water table tend to be overestimated (note the asymmetry in the blue curve of the 

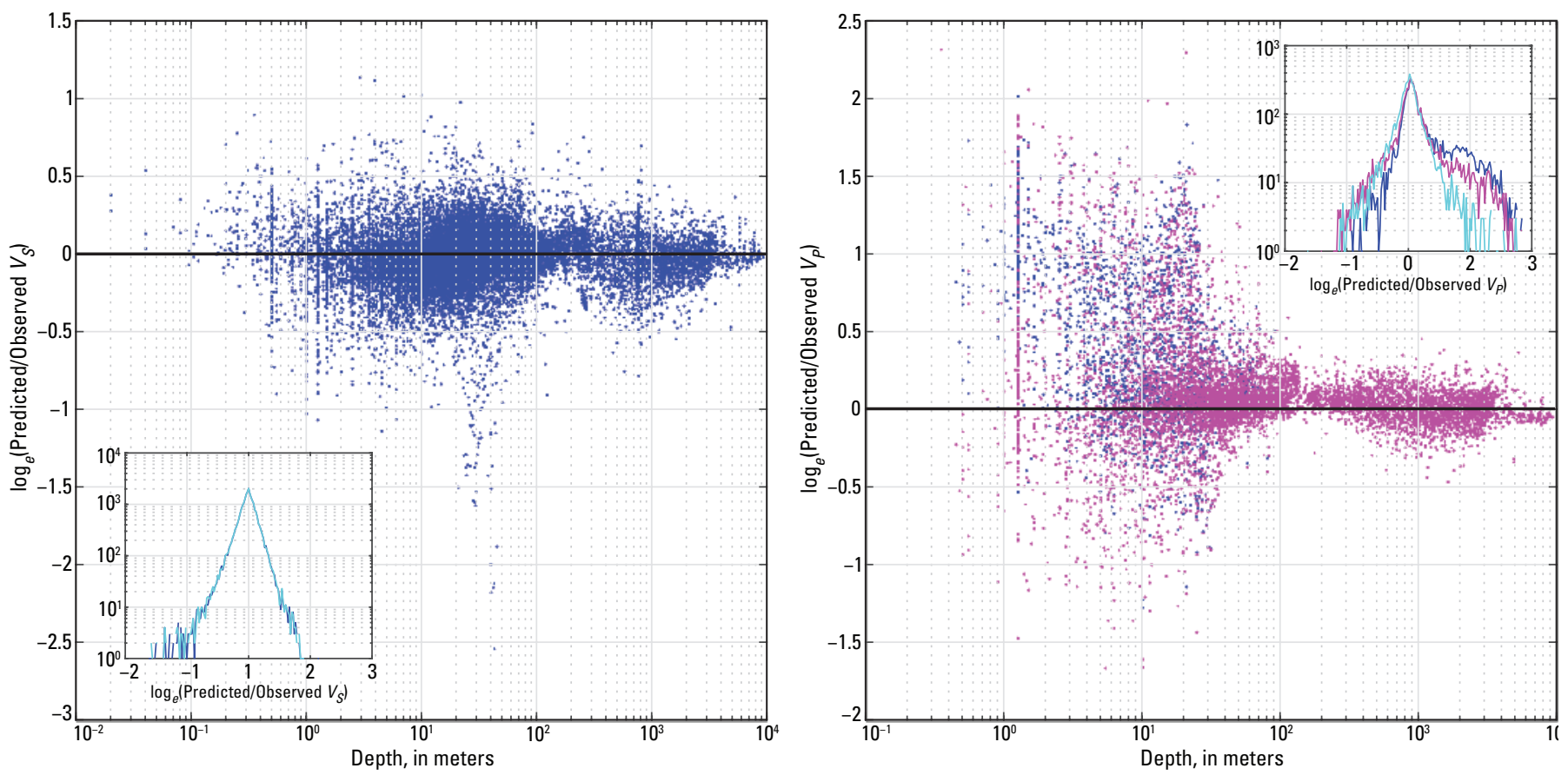

Figure 5. Ratio of predicted relative to observed shear-wave velocity ( $V_{S_{i}}$ left) and compressional-wave velocity ( $V_{p}$; right) versus depth by using adjusted geologic profiles with spatially varying $B$ values. In the plot on the right for $V_{P_{r}}$ blue dots represent the original Biot-Gassmann $\beta_{P}$ function, and magenta dots represent the modified $\beta_{P}$ function. Insets: histograms are for velocity values at depths less than 100 meters to emphasize the effect of the water table (practically no difference). For $V_{S}$, the blue curves represent the original water table, and the cyan curve represents the adjusted water table. For $V_{P}$ the blue curve represents the original $\beta_{P}$ function with the original water table, the magenta curve represents the modified $\beta_{P}$ function with the original water table, and the cyan curve represents the modified $\beta_{P}$ with the adjusted water table.

inset histogram in the right-hand graph in fig. 5). This problem can be solved if $\beta_{P}$ tends toward $\beta_{S}$ as the saturation above the water table decreases toward 0 percent:

$$
\beta_{P}=\beta_{P} S+\beta_{S}(1-S) \text {. }
$$

Upon examining equations 7 and 8 and the effect of this condition on the $V_{P} / V_{S}$ ratio, adopting equation 15 is equivalent to letting $\gamma$ equal 1 .

\section{Water Table}

One significant variable not yet introduced but readily apparent from the previous discussion is the depth to the water table and how saturation and pore pressure vary within the vadose zone and capillary fringe. As seen in figure $6, V_{P} / V_{S}$ ratios measured at relatively shallow (less than $1 \mathrm{~km}$ ) depths can vary over a large range and increase to values of more than 10 . This range of values is due to variations in porosity and the presence of material in the pore space with finite bulk modulus and no shear modulus. Higher porosities below the water table lead to higher $V_{P} / V_{S}$ ratios. Above the water table, as fluid in the pore space is replaced with air, the bulk modulus decreases, and the $V_{P} / V_{S}$ ratios return to values near 1.7.
In this work, the water-table model of Fan and others (2013) is used with modifications from observations of water levels in 10,597 wells across the United States available from the USGS National Water Information System (NWIS) and 1,575 wells in the greater Los Angeles area of southern California. Water-table depths range from $0 \mathrm{~m}$ near bodies of water to more than $100 \mathrm{~m}$ in much of the arid WUS (fig. 7). The information from the NWIS is available as a time series, which allows for a measure of seasonality and standard deviation. The median water-table depth observed in wells in the central and eastern United States, east of -100 degrees longitude, was $6 \mathrm{~m}$ with a standard deviation of $0.5 \mathrm{~m}$. In the WUS (west of -100 degrees longitude), it was $26 \mathrm{~m}$ with a standard deviation of $1 \mathrm{~m}$.

Above the water table, the capillary fringe is the lesser of $0.5 \mathrm{~m}$ or the depth to the water table. Above the capillary fringe lies the vadose zone, which is assumed to extend to the Earth's surface with a saturation $S$ that follows half of a scaled sine wave from 0- to 100-percent saturation (for example, see fig. 9.4.1 in Bear [1972]):

$$
S=\left[\frac{\sin \left(\pi \frac{d-d_{V}}{d_{C}-d_{\nu}}-\frac{\pi}{2}\right)+1}{2}\right]^{2},
$$




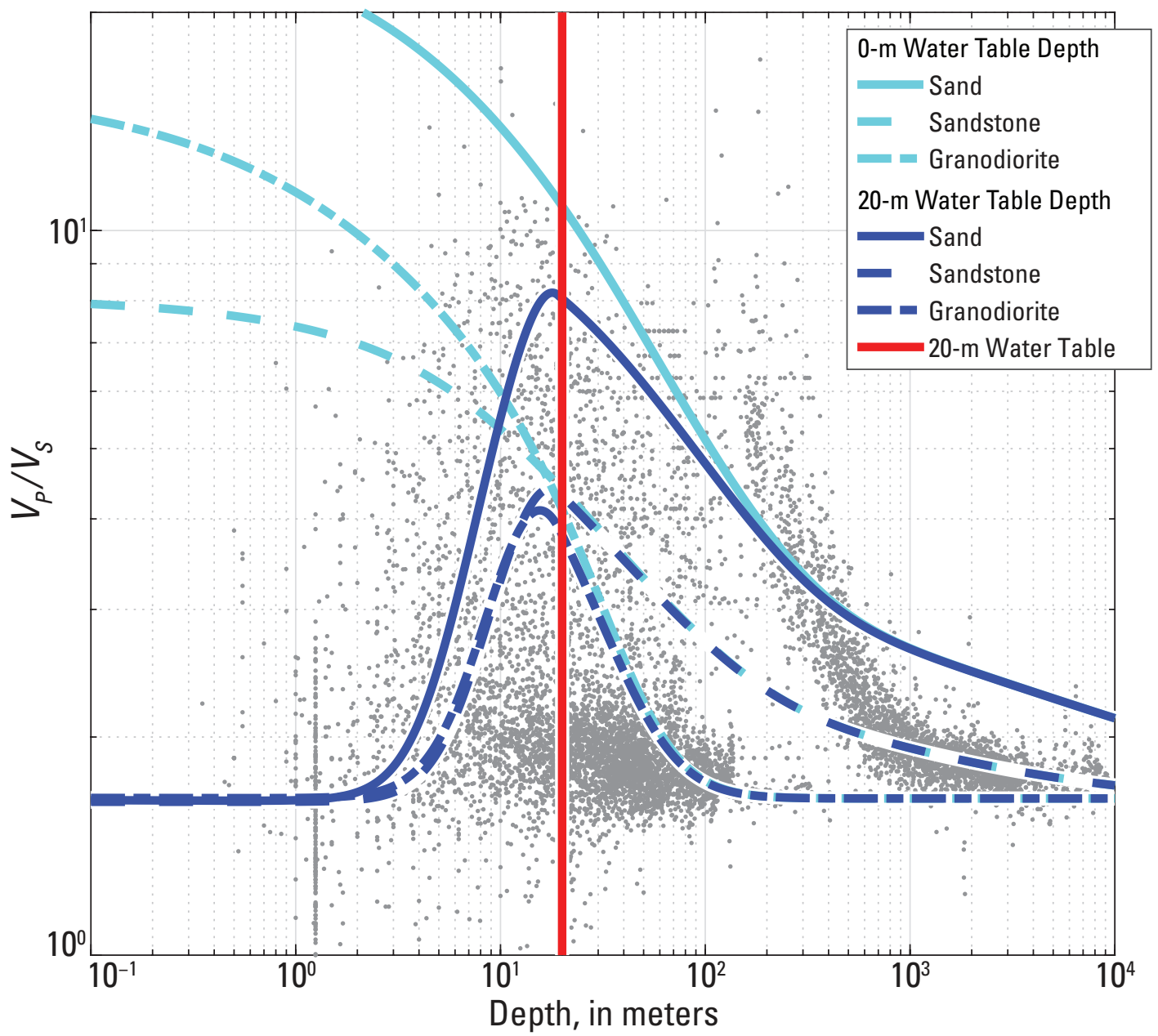

Figure 6. Observed $V_{P} / V_{S}$ ratios versus depth (gray dots) as well as predicted relations for Quaternary sand (solid lines), Late Cretaceous sandstone (dashed lines), and Mesozoic granodiorite (alternating short and long dashes) with a water-table depth of 20 meters $(\mathrm{m})$ (blue) and $0 \mathrm{~m}$ (cyan).

where $d$ is depth, $d_{V}$ is the depth to the top of the vadose zone, and $d_{C}$ is the depth to the top of the capillary fringe. Fluid pressure within the vadose zone is taken from the formulation of $\mathrm{Lu}$ and others (2010) with parameters for sand $(a=0.3, n=3)$ :

$$
P=-1000 \frac{S}{a}\left(S_{1-n}^{\frac{n}{1-n}}-1\right)^{\frac{1}{n}}
$$

With the porosity models for each lithology-age combination reported in the "Results" section, water-table values are further modified at velocity-profile locations in order to best match the observed $V_{P}$ (cyan histograms in fig. $5 B$ ). This modification is done only for locations in the WUS that have both $V_{P}$ and $V_{S}$ with initial water-table depths greater than half of the depth of the first observed velocity value. The results are changes at 441 locations and an increase in the median water-table depth from 20 to $23 \mathrm{~m}$, which is closer to the median of $26 \mathrm{~m}$ from the NWIS dataset for the WUS. 


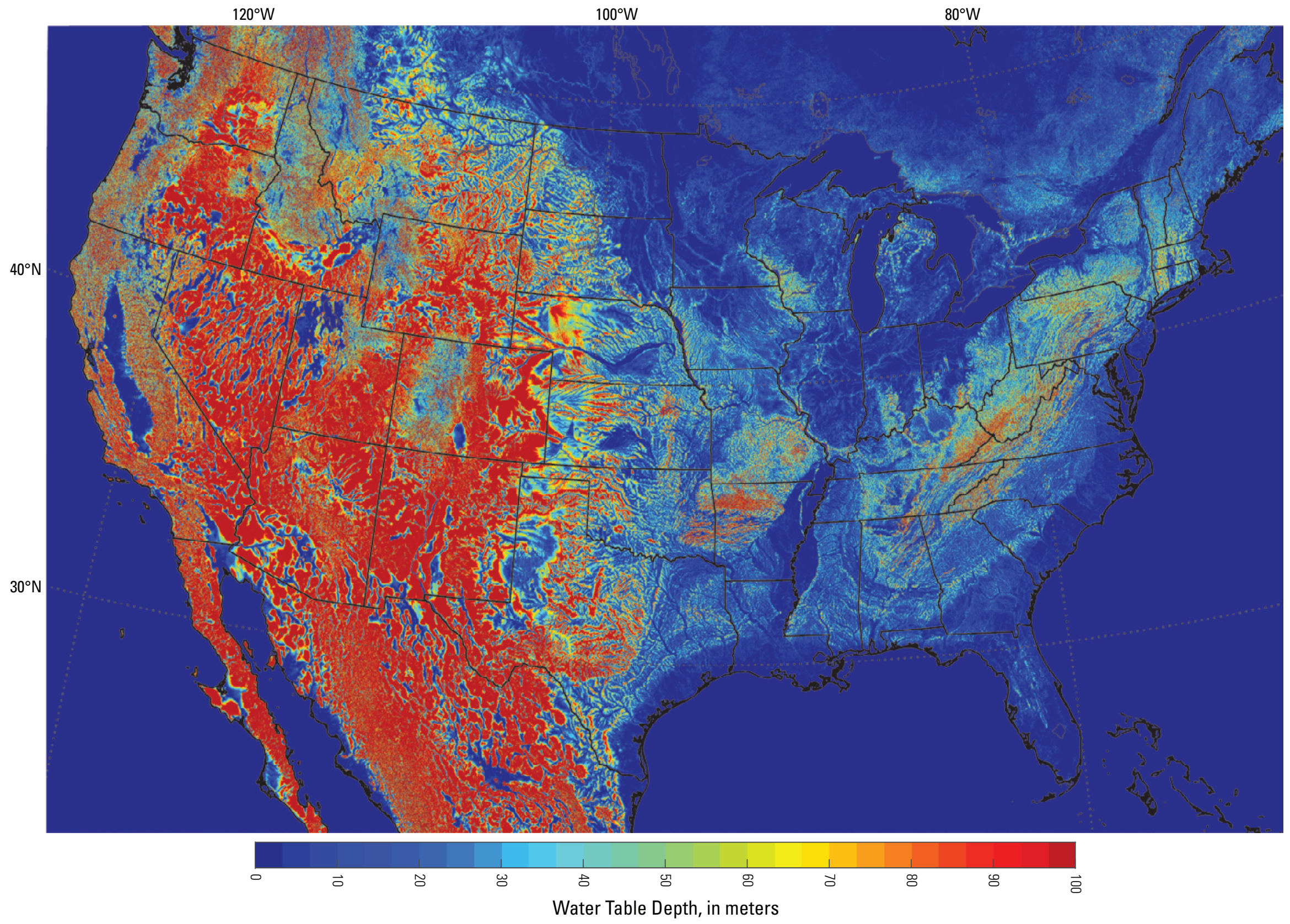

Figure 7. Water-table depths across the National Crustal Model. 


\section{Velocity Variability}

The calibration presented here is a simplification of the actual conditions within the Earth. Geologic units have inherent variability in lithology and porosity. Water saturation within the porous rocks may be highly variable due to the volume of disconnected porosity, perched water tables, pumping, and other factors. Furthermore, predicting velocities can be hampered by imprecise knowledge of the subsurface geology, as indicated by the many adjustments described in the "Subsurface Geology" section as needed to calibrate this model.

If the geologic model is assumed to be known (from the adjustments made for calibration), and the $B$ values for each layer within each profile and depth to water table are known (from the fitting during calibration), termed the ideal NCM, bias is less than 1 percent, and $V_{S}$ predictions differ from observations with a standard deviation of $0.17 \log _{e}$ units. $V_{P}$ predictions will differ from observations with a standard deviation of $0.41 \log _{e}$ units based on the initial water-table depths and will drop to $0.26 \log _{e}$ units with the revised water-table depths. In many areas, however, no subsurface observations are available to adjust the geologic model and optimize the $B$ value and depth to the water table. In this most general case, $V_{S}$ is underpredicted by 4 percent, and $V_{P}$ is overpredicted by 9 percent, on average. $V_{S}$ and $V_{P}$ predictions both differ from observations with a standard deviation of $0.58 \log _{e}$ units. Regional variations, however, are significant and are discussed in the next section.

\section{Comparison with Existing Geophysical Models}

Regional velocity models have been constructed around Los Angeles (Kohler and others, 2003; Shaw and others, 2015) and San Francisco (Aagaard and others, 2010), California; Seattle, Washington (Stephenson and others, 2017); and Salt Lake City, Utah (Magistrale and others, 2008). These models make use of a host of information from tomography to reflection seismology to gravimetric studies to information obtained from boreholes.

In many cases, they convert $V_{P}$ to $V_{S}$ by assuming standard empirical relationships (Brocher, 2005b). For example, in the Bay Area, empirical $V_{P}$-depth relationships have been derived for 14 rock types and 2 locations (the Great Valley and La Honda Basin). $V_{S}$ is derived from $V_{P}$ by applying various rules, except for shallow Cenozoic sedimentary deposits (less than $40 \mathrm{~m}$ deep), which have their own unique $V_{S}$-depth relationship. The resulting $V_{P} / V_{S}$ values are broadly consistent with those shown in figure 6 except that they do not explicitly account for porosity or the depth to the water table. Shallow $V_{P} / V_{S}$ ratios in unsaturated sediments increase from a value of 2.5 at the surface to 4.0 at $40 \mathrm{~m}$ depth. At greater depths, $V_{P} / V_{S}$ ratios in these units follow Castagna and others' (1985) "mudline," decreasing from almost 7 at $40-\mathrm{m}$ depth to 2.5 at $500-\mathrm{m}$ depth. In volcanic, igneous, and metamorphic rocks, $V_{P} / V_{S}$ is derived from Brocher's (2005b) relation where $V_{P} / V_{S}$ decreases from 4.5 at a $V_{P}$ of $1.5 \mathrm{~km} / \mathrm{s}$ to about 1.7 at a $V_{P}$ greater than $5 \mathrm{~km} / \mathrm{s}$, with the exception of some lithologies that transition to the "mafic line" above about $4 \mathrm{~km} / \mathrm{s}$, which increases the $V_{P} / V_{S}$ ratio.

In Seattle, a variety of generally non-overlapping $V_{P}$ and $V_{S}$ datasets were available, and conversions for most of the model domain were handled by using Brocher's (2005b) relations with exceptions for Cenozoic continental units. For Quaternary deposits with $V_{P}$ determined from land-surface measurements and marine surveys, a $V_{P} / V_{S}$ ratio of 2.5 at Earth's surface was assumed. This ratio was determined from time-averaged $V_{P}$ and $V_{S}$ values measured in the top $30 \mathrm{~m}$ of the Quaternary section. The ratio decreases linearly to a value of 2.2 at $1-\mathrm{km}$ depth (the maximum thickness of Quaternary sediments) and drops to 2 in the underlying Tertiary sedimentary units (Stephenson and others, 2017).

Deviations between observed and modeled $V_{S}$ for two southern California models (Kohler and others, 2003-model denoted as cvms426m01; Shaw and others, 2015-model denoted as cvmh1510), for which geophysical information was obtained by using the Southern California Earthquake Center's Unified Community Velocity Model software framework (Small and others, 2017), are relatively large, on average (fig. 8). These models include a geotechnical layer allowing for shear-wave velocities down to $100 \mathrm{~m} / \mathrm{s}$ within tens of meters of the surface. With the application of detailed structural and geophysical information used to characterize the basins in and around Los Angeles, these models produce relatively reliable information about the basins but generally cannot reproduce details below shear-wave velocities of $1 \mathrm{~km} / \mathrm{s} V_{S}$ outside of these basins. Hence, averaging over all locations where $V_{S}$ is observed within their model domains, these models may overpredict $V_{S}$ by a factor of 2 , increasing from near 1 at

Figure 8 (following page). Shear-wave velocity ( $V_{S}$; left), compressional-wave velocity ( $V_{p}$; center), and density $(\rho$; right) misfit comparisons for several regions from Vancouver, British Columbia, to southern California. The red circles represent an ideal National Crustal Model (NCM), where the geology is assumed to be known; $B$ values are fit to each lithology within each profile; and water-table depths are adjusted for four of the slowest profiles. Blue stars represent the NCM without refinement. Yellow squares represent the results from established geophysical models of the San Francisco Bay Area-(abbreviated as "bayarea") and southern California(abbreviated as "cvmh" and "cvms426m01"). Polygons, the colored areas around the symbols, show the 5- to 95-percent regions in which the misfits lie. The dashed black line indicates the misfit of a profile with constant velocity or density. An ideal NCM is not shown for density misfits because the geologic profiles and $B$-values were not adjusted at these locations. 

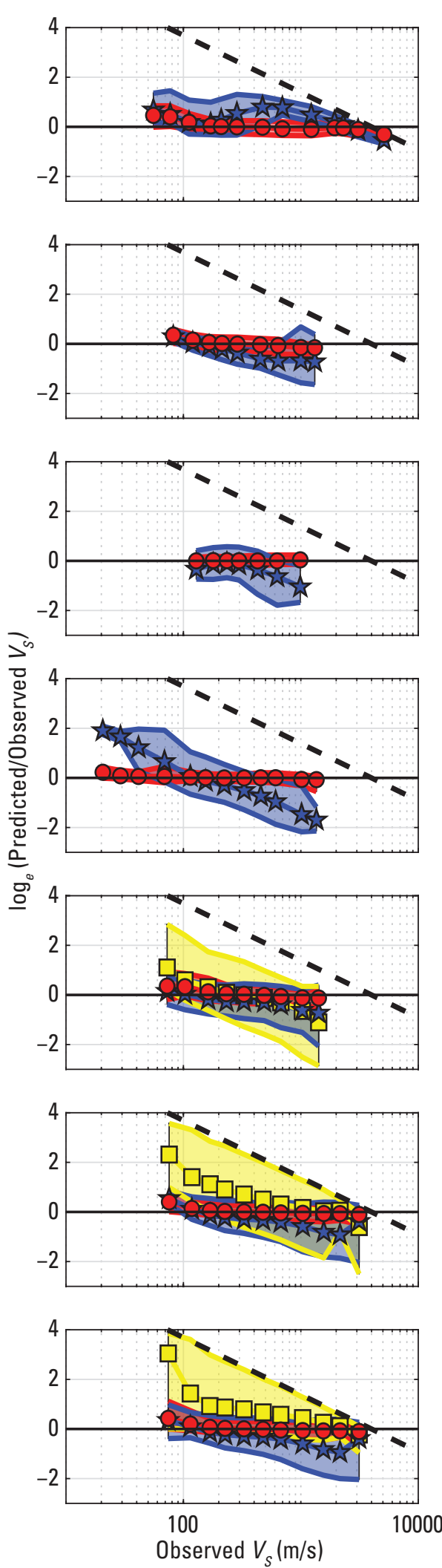

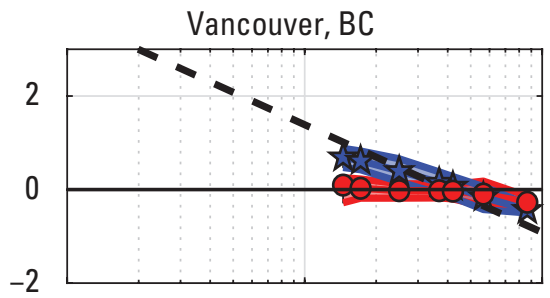

Wasatch Front, Utah
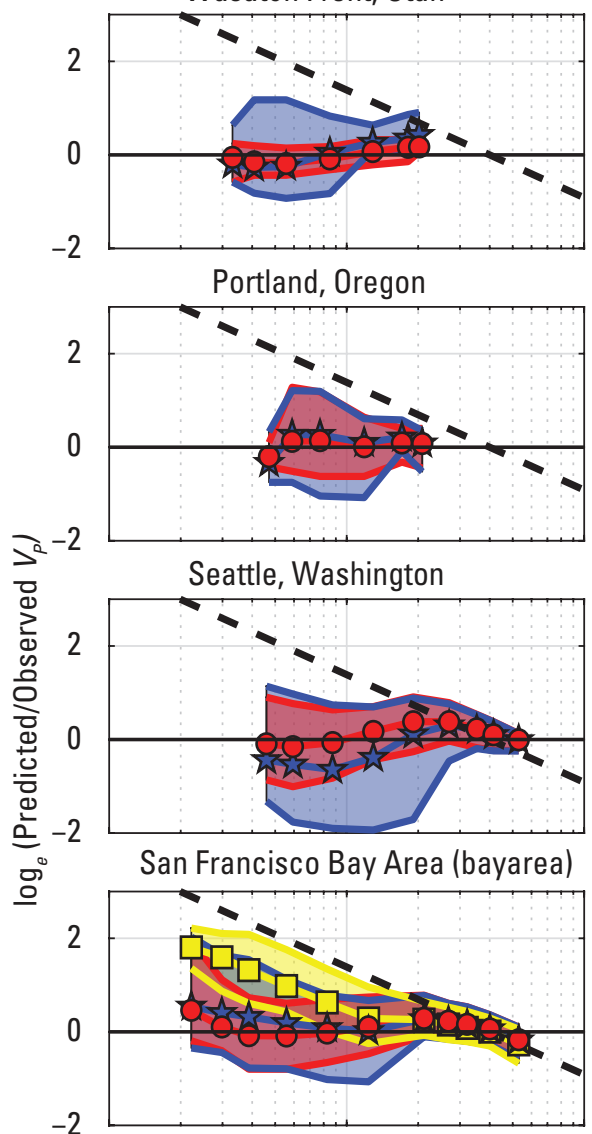

Southern California (cvmh)

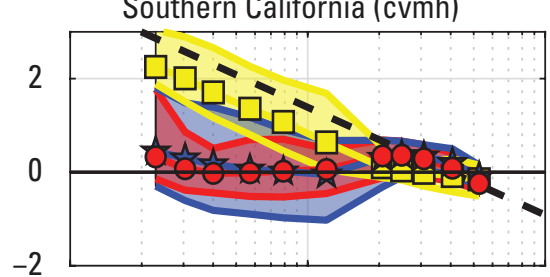

Southern California (cvms426m01)

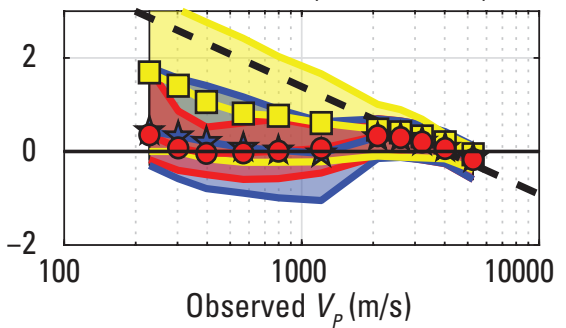

O Ideal NCM

公 NCM

Regional Model
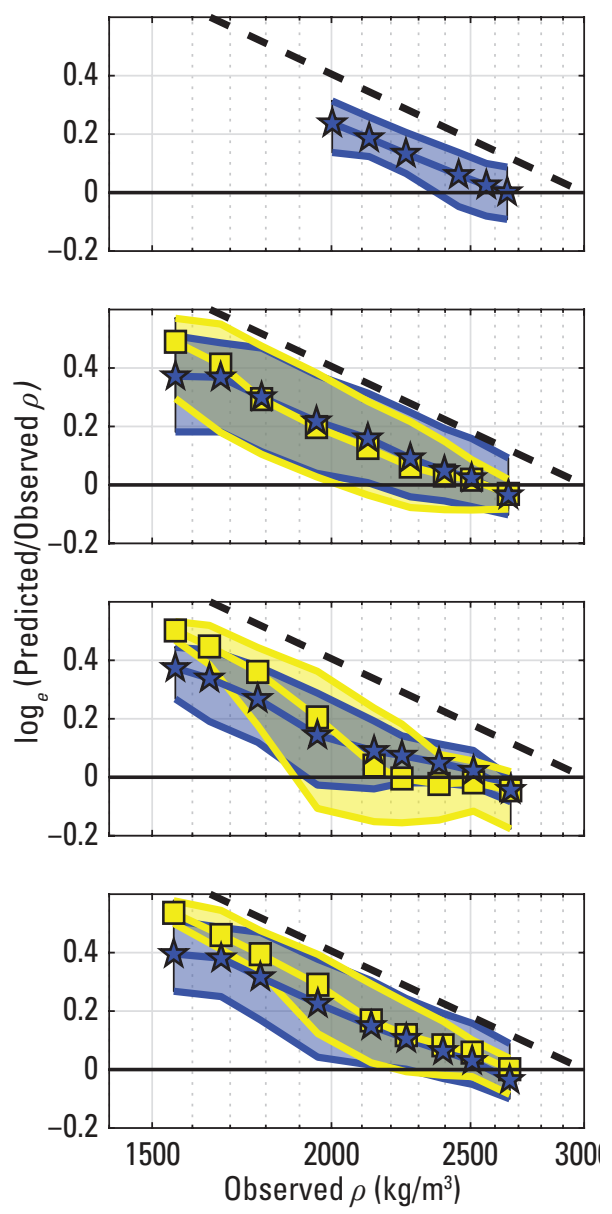
about $2 \mathrm{~km} / \mathrm{s}$ to more than a factor of 4 at $100 \mathrm{~m} / \mathrm{s}$. In contrast, resolution of the Bay Area model is more uniform with a high-resolution rectangular region surrounded by a lower resolution rectangular region. The model underpredicts the observations by only 5 percent on average but tends to deviate to the high side at $V_{S}$ less than $300 \mathrm{~m} / \mathrm{s}$ and to the low side at $V_{S}$ greater than $300 \mathrm{~m} / \mathrm{s}$.

Investigating the $\mathrm{NCM}$ by region reveals important distinctions (fig. 8). Where the NCMGF is not fully developed to the northwest in Vancouver, British Columbia, the velocity profiles clearly indicate that the depth to bedrock and basement is too shallow in the NCMGF. This leads the $\mathrm{NCM}$ to overpredict $V_{S}$ by as much as a factor of 2 between the bedrock and basement NCMGF transitions or between $V_{S}$ values of about 200 and $2,000 \mathrm{~m} / \mathrm{s}$. In regions with a better developed NCMGF, important geologic contrasts need refinement, particularly within the Quaternary section. For example, the depth of the contact between the seismically slower Holocene lake and marine sediment and the underlying faster Pleistocene glacial drift in the Seattle area is probably shallower than the depth specified in the NCMGF, as inferred from the velocity profiles. The NCMGF without refinement leads to an underprediction of $V_{S}$ above $100 \mathrm{~m} / \mathrm{s}$ that progressively increases with increasing $V_{S}$. In the valleys of the Mojave Desert of southern California, the rapid increases of the observed $V_{S}$ indicate that basement rock may be shallower than depicted in the NCMGF. This too leads to an underprediction of $V_{S}$, primarily between about 1 and $2 \mathrm{~km} / \mathrm{s}$.

Comparisons with $V_{P}$ seem to tell a different story (fig. 8). All three California models tend to overpredict observed $V_{P}$ for $V_{P}$ values less than about $2 \mathrm{~km} / \mathrm{s}$. For the southern California models, this overprediction may be due to the use of the geotechnical layer (that is, the low-seismic velocity layer at and near the Earth's surface) only in the calculation of $V_{S}$. The zone above the water table may also exert some influence. In figure $6, V_{P} / V_{S}$ ratios drop to 1.7 , but in the Bay Area model, for example, $V_{P} / V_{S}$ ratios increase from 2.5 at the surface to 4 at $40 \mathrm{~m}$ depth. In the NCM, $V_{P}$ is slightly overpredicted for the Bay Area and southern California, and in Seattle, below $2 \mathrm{~km} / \mathrm{s}$ is a stronger underprediction. As is the case for $V_{S}$, the discrepancy in Seattle may be due to problems resolving the depth of important geologic contacts in the shallow surface.

All models tend to increasingly overestimate density as density decreases. Significant contributions to this misfit with regard to the NCM include but are not limited to the following three conditions:

1. A single set of constants that were used for $m$ and $\alpha$ (equations 11 and 12). These constants are based on data for unconsolidated sands. Although estimates of density are much less biased for the alluvium and sandstones represented in this dataset, conceivably these constants likely differ by rock type. For example, a high-porosity limestone or basalt may have a relatively strong structural framework leading to a high seismic velocity but also relatively low density.
2. Another contributor could be problems with the NCMGF. Geologic assignments were not adjusted at the locations of density profiles, but a cursory comparison suggests that at one location in the southern Bay Area, the estimated depth to basement used in the NCMGF might be too shallow.

3. Finally, issues may relate to saturation. The NCM assumes 100-percent saturation below the water table, but pumping from confined aquifers will reduce saturation in these areas and thereby reduce both density and $V_{P}$.

The spread in $V_{S}$ misfit between 5 and 95 percent of the median is relatively constant between about 2.5 and $3 \log _{e}$ units for the cvmh1510 and Bay Area models and decreases steadily for cvms $426 \mathrm{~m} 01$ from about 4 at $100 \mathrm{~m} / \mathrm{s}$ to less than 1 at $2 \mathrm{~km} / \mathrm{s}$. This steady decrease may have been caused by iterative tomographic methods that were used to refine the original model (Lee and others, 2014). The spread for the $\mathrm{NCM}$ without refinement peaks at almost 2.4 near $700 \mathrm{~m} / \mathrm{s}$, and drops to just under 0.5 at $3 \mathrm{~km} / \mathrm{s}$ and down to 1.7 at $100 \mathrm{~m} / \mathrm{s}$. For the ideal NCM, where geology is assumed to be known and the $B$ values and depth to water table are optimized for each profile, the spread decreases to about 0.5 for all values of $V_{S}$.

Deviations for the Seattle and Salt Lake City models were not investigated. The Seattle model available from ScienceBase (Stephenson, 2017) provides a model with only $500 \mathrm{~m}$ of vertical resolution, which is insufficient for comparison. In the Salt Lake City model, little to no deviation from the measured data probably exists because of the way in which the model was constructed. The Salt Lake City velocity model was built to honor borehole observations exactly within a specific distance of their locations, and the borehole data that were used to produce the Salt Lake City model were the only Salt Lake City observations used in this study. The initial Los Angeles model, designated as cvms (Kohler and others, 2003), was also built in this way but has since been modified by the use of other methods and additional data (Lee and others, 2014).

\section{Discussion}

Several primary uses for these existing models include earthquake simulations and maps of $Z_{1.0}$ and $Z_{2.5}$. Earthquake simulations have resulted in rich datasets which reveal the complexity of earthquake ground motions - for example, as seismic waves enter, are focused by, and reverberate within sedimentary basins. The simulations are expected to lead to far more accurate hazard analyses. Maps of $Z_{1.0}$ and $Z_{2.5}$, on the other hand, are used to calibrate GMMs. They are also applied to GMMs in hazard analyses for southern California, the Bay Area, and with modification in Puget Sound, Washington (Petersen and others, 2019). 
Fortunately, the bias in shear-wave velocities below $1 \mathrm{~km} / \mathrm{s}$ observed in existing California models may not be a problem. Earthquake simulations can require a minimum shear-wave velocity of $500 \mathrm{~m} / \mathrm{s}$ because of computational limitations, and in the more populated basin areas where the Bay Area and Los Angeles models are better constrained, the bias above $500 \mathrm{~m} / \mathrm{s}$ is not significant. Any potential bias is also not a problem for GMMs if the $Z_{1.0}$ or $Z_{2.5}$ map that was used to calibrate the GMM is the same map that is used in its application. As earthquake simulations become sensitive to lower velocities and as more of the velocity profile is used to construct site-amplification functions, however, greater attention will need to be given to the lowest velocities near the surface and to how rapidly velocities increase with depth.

Discrepancies between observed and predicted seismic velocity and density provide a roadmap for ways in which the NCM could be improved. For example, additional analysis is needed to better determine the variability of the dependences of porosity and elastic modulus on rock type. Another avenue of improvement relates to the NCMGF. Other geologic framework models, specifically hydrogeologic models (for example, Sweetkind and others, 2019, and references therein), have been developed for the WUS but have not been incorporated into the NCMGF. Furthermore, the underlying assumptions used to produce geologic structures within the NCMGF are not necessarily consistent with elements of the NCM. For example, the sedimentary-density profile used in gravity analysis of the Basin and Range Province of the WUS (Saltus and Jachens, 1995; Shah and Boyd, 2018) and from which the resulting bedrock- and basement-depth model is incorporated into the NCMGF, is based on a simple four-layer density structure in which the density of the sediments in the upper $200 \mathrm{~m}$ is 650 kilograms per cubic meter $\left(\mathrm{kg} / \mathrm{m}^{3}\right)$ less than the density of the pre-Cenozoic basement. In contrast, the NCM, for example, predicts a density deficit of at least $800 \mathrm{~kg} / \mathrm{m}^{3}$ in the upper $200 \mathrm{~m}$ of Holocene alluvium in Las Vegas. If the density contrasts and gradients are greater than assumed in the gravity studies, the depths to bedrock and basement may be overestimated. Using the density-depth functions from the NCM with improved rock-dependent, elastic modulus-porosity relationships could lead to a more accurate NCMGF and resulting geophysical model.

\section{Conclusions}

A calibration of a porosity model for geologic units within the U.S. Geological Survey National Crustal Model (NCM) is presented to estimate shear-wave and compressional-wave velocities and densities as functions of depth, rock type, and rock age. Minor modifications to the Biot-Gassmann theoretical framework are needed to match observed low shear-wave and compressional-wave velocities above the water table. The resulting calibration yields an NCM that has little overall average bias between 100 meters per second and 3 kilometers per second shear-wave velocities; however, a strong regional variability in bias is due in part to imperfect knowledge of the subsurface geologic structure. Compressional-wave velocities have relatively low overall average and regional bias values between 200 meters per second and 5 kilometers per second, but uncertainty is greater at lower velocities due to imprecise knowledge of the depth to the water table and degree of saturation. On average, densities tend to be overpredicted, which may indicate unmodeled variability in the relationships between porosity and elastic modulus.

This calibration and the components of the NCM can be used in seismic hazard analyses by extracting the time-averaged shear-wave velocities in the upper 30 meters and the depths to 1.0 and 2.5 kilometers per second shear-wave velocity, which are parameters needed for current ground motion models. The NCM can also be used to produce more sophisticated site-response metrics or for earthquake simulations. Although the modeling of existing observations has been verified, the calibrations and components of the NCM have not been validated. The NCM will need to be validated for each of the aforementioned applications before a given product extracted from the NCM can be considered for policy decisions.

\section{References Cited}

Aagaard, B.T., Graves, R.W., Rodgers, A., Brocher, T.M., Simpson, R.W., Dreger, D., Petersson, N.A., Larsen, S.C., Ma, S., and Jachens, R.C., 2010, Ground motion modeling of Hayward fault scenario earthquakes, Part II-Simulation of long-period and broadband ground motions: Bulletin of the Seismological Society of America, v. 100, no. 6, p. 2945-2977.

Ahdi, S.K., Stewart, J.P., Ancheta, T.D., Kwak, D.Y., and Mitra, D., 2017, Development of VS profile database and proxy-based models for VS30 prediction in the Pacific Northwest region of North America: Bulletin of the Seismological Society of America, v. 107, no. 4, p. 1781-1801.

Bear, J., 1972, Dynamics of fluids in porous media: New York, American Elsevier, 764 p.

Boore, D., 2003, A compendium of P- and S-wave velocities from surface-to-borehole logging; summary and reanalysis of previously published data and analysis of unpublished data: U.S. Geological Survey Open-File Report 2003-191, 13 p., accessed June 15, 2019, at https://doi.org/10.3133/ ofr03191.

Boyd, O.S., 2019, 3D geologic framework for use with the U.S. Geological Survey National Crustal Model, phase 1Western United States: U.S. Geological Survey Open-File Report 2019-1081, 36 p. [Also available at https://doi.org/ 10.3133/ofr20191081.] 
Boyd, O.S., 2020a, Calibration coefficients for the U.S. Geological Survey National Crustal Model and depth to water table: U.S. Geological Survey data release, https://doi.org/10.5066/P9GO3CP8.

Boyd, O.S., 2020b, Temperature model in support of the U.S. Geological Survey National Crustal Model for seismic hazard studies: U.S. Geological Survey Open-File Report 2019-1121, 15 p., accessed February 4, 2020, at https://doi.org/10.3133/ofr20191121.

Brocher, T.M., 2005a, A regional view of urban sedimentary basins in northern California based on oil industry compressional-wave velocity and density logs: Bulletin of the Seismological Society of America, v. 95, no. 6, p. 2093-2114, accessed March 1, 2017, at https://doi.org/ $10.1785 / 0120050025$.

Brocher, T.M., 2005b, Empirical relations between elastic wavespeeds and density in the Earth's crust: Bulletin of the Seismological Society of America, v. 95, no. 6, p. 2081-2092.

Brocher, T.M., and Horta, E., 1998, Compilation of 19 sonic and density logs from 10 oil test wells in southwestern Oregon: U.S. Geological Survey Open-File Report 98-237, 38 p. [Also available at https://doi.org/10.3133/ofr98237.]

Brocher, T.M., and Ruebel, A.L., 1998, Compilation of 29 sonic and density logs from 23 oil test wells in western Washington State: U.S. Geological Survey Open-File Report 98-249, 60 p. [Also available at https://doi.org/ 10.3133/ofr98249.]

Brocher, T.M., Ruebel, A.L., Wright, T.L., and Okaya, D.A., 1998, Compilation of 20 sonic and density logs from 12 oil test wells along LARSE Lines 1 and 2, Los Angeles Region, California: U.S. Geological Survey Open-File Report 98-366, 54 p. [Also available at https://doi.org/ 10.3133/ofr98366.]

Castagna, J.P., Batzle, M.L., and Eastwood, R.L., 1985, Relationships between compressional-wave and shear-wave velocities in clastic silicate rocks: Geophysics, v. 50, p. 571-581.

Fan, Y., Li, H., and Miguez-Macho, G., 2013, Global patterns of groundwater table depth: Science, v. 339, no. 6122, p. $940-943$.

Garrity, C.P., and Soller, D.R., 2009, Database of the Geologic Map of North America-Adapted from the map by J.C. Reed, Jr., and others (2005): U.S. Geological Survey Data Series $424,7 \mathrm{p}$.

Gibbs, J.F., Fumal, T.E., Boore, D.M., and Joyner, W.B., 1992, Seismic velocities and geologic logs from borehole measurements at seven strong-motion stations that recorded the Loma Prieta earthquake: U.S. Geological Survey Open-File Report 92-287, 142 p.
Hashash, Y.M.A., Kottke, A.R., Stewart, J.P., Campbell, K.W., Kim, B., Moss, C., Nikolaou, S., Rathje, E.M., and Silva, W.J., 2014, Reference rock site condition for Central and Eastern North America: Bulletin of the Seismological Society of America, v. 104, no. 2, p. 684-701.

Kansas Geological Survey, 2017, LAS File Database, accessed February 19, 2017, at http://www.kgs.ku.edu/ Magellan/Logs/.

Kohler, M.D., Magistrale, H., and Clayton, R.W., 2003, Mantle heterogeneities and the SCEC reference three-dimensional seismic velocity model version 3 : Bulletin of the Seismological Society of America, v. 93, p. 757-774.

Lee, E., Chen, P., Jordan, T.H., Maechling, P.J., Denolle, M.A., and Beroza, G.C., 2014, Full-3-D tomography for crustal structure in Southern California based on the scattering-integral and the adjoint-wavefield methods: Journal of Geophysical Research, v. 119, no. 8, p. 6421-6451.

Lee, M.W., 2005, Proposed moduli of dry rock and their application to predicting elastic velocities of sandstones: U.S. Geological Survey Scientific Investigations Report 2005-5119, 14 p., accessed September 5, 2019, at https://doi.org/10.3133/sir20055119.

Lee, M.W., 2010, Predicting S-wave velocities for unconsolidated sediments at low effective pressure: U.S. Geological Survey Scientific Investigations Report 2010-5138, 13 p., accessed June 4, 2019, at https://doi.org/ $10.3133 / \operatorname{sir} 20105138$.

Lu, N., Godt, J.W., and Wu, D.T., 2010, A closed-form equation for effective stress in unsaturated soil: Water Resources Research, v. 46, issue 5, 14 p., accessed January 25, 2018, at https://doi.org/10.1029/2009WR008646.

Magistrale, H., Olsen, K., and Pechmann, J., 2008, Construction and verification of a Wasatch Front community velocity model - Collaborative research with San Diego State University and the University of Utah-Final technical report: Reston, Va., U.S. Geological Survey report, prepared by San Diego State University and the University of Utah under contracts 05HQGR0006, 05HQGR0011, 06HQGR0009, and 06HQGR0012, 14 p., accessed February 27, 2020, at https://earthquake.usgs.gov/cfusion/ external_grants/reports/05HQGR0006.pdf.

Mavko, G., and Mukerji, T., 1998, Bounds on low-frequency seismic velocities in partially saturated rocks: Geophysics, v. 63 , no. 3, p. 918-924.

Mooney, W.D., 2013, Database of Central and Eastern North American (CENA) Seismic Velocity Structure (Task 2 of USGS-NRC Work Agreement 2011-2014): United States Nuclear Regulatory Commission, Agencywide Documents Access and Management System (ADAMS) accession number ML14280A412, 231 p., accessed February 27, 2020, at https://adams.nrc.gov/wba/. 
Mustard, P.S., and Rouse, G.E., 1994, Stratigraphy and evolution of the Tertiary Georgia Basin and subjacent Upper Cretaceous sedimentary rocks, southwestern British Columbia and northwestern Washington State, in Monger, J.W.H., ed., Geology and geological hazards of the Vancouver region, southwestern British Columbia: Geological Survey of Canada Bulletin 481, p. 97-169, accessed August 2, 2019, at https://doi.org/10.4095/203244.

Pelletier, P., Broxton, D., Hazenberg, P., Zeng, X., Troch, P.A., Niu, G.-Y., Williams, Z., Brunke, M.A., and Gochis, D., 2016, A gridded global data set of soil, immobile regolith, and sedimentary deposit thicknesses for regional and global land surface modeling: Journal of Advances in Modeling Earth Systems, v. 8, issue 1, p. 41-65, accessed June 26, 2017, at https://doi.org/10.1002/2015MS000526.

Petersen, M.D., Shumway, A.M., Powers, P.M., Mueller, C.S., Moschetti, M.P., Frankel, A.D., Rezaeian, S., McNamara, D.E., Luco, N., Boyd, O.S., Rukstales, K.S., Jaiswal, K.S., Thompson, E.M., Hoover, S.M., Clayton, B.S., Field, E.H., and Zeng, Y., 2019, 2018 update of the U.S. National Seismic Hazard ModelOverview of model and implications: Earthquake Spectra, v. 36, issue 1, p. 5-41. [Also available at https://doi.org/ 10.1177\%2F8755293019878199.]

Saltus, R.W., and Jachens, R.C., 1995, Gravity and basin-depth maps of the Basin and Range Province, Western United States: U.S. Geological Survey Geophysical Investigation Map 1012, 1 pl., scale 1: 2,500,000, accessed January 18, 2020, at https://doi.org/10.3133/gp1012.

Shah, A.K., and Boyd, O.S., 2018, Depth to basement and thickness of unconsolidated sediments for the western U.S.Layers of the USGS National Crustal Model, version 1.0: U.S. Geological Survey Open-File Report 2018-1115, 13 p. [Also available at https://doi.org/10.3133/ofr20181115.]

Shaw, J.H., Plesch, A., Tape, C., Suess, M.P., Jordan, T.H., Ely, G., Hauksson, E., Tromp, J., Tanimoto, T., Graves, R., Olsen, K., Nicholson, C., Maechling, P.J., Rivero, C., Lovely, P., Brankman, C.M., and Munster, J., 2015, Unified structural representation of the southern California crust and upper mantle: Earth and Planetary Science Letters, v. 415, p. 1-15, accessed March 17, 2017, at https://doi.org/ 10.1016/j.eps1.2015.01.016.

Shi, J., and Asimaki, D., 2018, A generic velocity profile for basin sediments in California conditioned on VS30: Seismological Research Letters, v. 89, no. 4, p. 1397-1409, accessed May 23, 2018, at https://doi.org/10.1785/ 0220170268 .

Small, P., Gill, D., Maechling, P.J., Taborda, R., Callaghan, S., Jordan, T.H., Ely, G.P., Olsen, K.B., and Goulet, C.A., 2017, The SCEC Unified Community Velocity Model software framework: Seismological Research Letters, v. 88 , no. 5., p. 1530-1552, accessed December 1, 2017, at https://doi.org/10.1785/0220170082.
Sowers, T., and Boyd, O.S., 2019, Petrologic and mineral physics database for use with the USGS National Crustal Model: U.S. Geological Survey Open-File Report 2019-1035, 17 p. [Also available at https://doi.org/10.3133/ ofr20191035.]

Stephenson, W.J., 2017, Data for P- and S-wave seismic velocity models incorporating the Cascadia subduction zone for 3D earthquake ground motion simulations-Update for Open-File Report 2007-1348: U.S. Geological Survey data release, accessed December 1, 2019, at https://doi.org/ 10.5066/F7NS0SWM.

Stephenson, W.J., Odum, J.K., Williams, R.A., McBride, J.H., and Tomlinson, I., 2012, Characterization of intrabasin faulting and deformation for earthquake hazards in southern Utah Valley, Utah, from high-resolution seismic imaging: Bulletin of the Seismological Society of America, v. 102 , no. 2, p. 524-540, accessed February 28, 2017, at https://doi.org/10.1785/0120110053.

Stephenson, W.J., Reitman, N.G., and Angster, S.J., 2017, P- and S-wave velocity models incorporating the Cascadia subduction zone for 3D earthquake ground motion simulations, version 1.6-Update for Open-File Report 2007-1348: U.S. Geological Survey Open-File Report 2017-1152, 17 p., accessed September 25, 2018, at https://doi.org/10.3133/ofr20171152.

Sweetkind, D., Graymer, R., Higley, D., and Boyd, O., 2019, Status of three-dimensional geological mapping and modelling activities in the U.S. Geological Survey, chap. 26 of MacCormack, K.E., Berg, R.C., Kessler, H., Russell, H.A.J., and Thorleifson, L.H., eds., 2019, 2019 synopsis of current three-dimensional geological mapping and modelling in geological survey organizations: Alberta Energy Regulator/Alberta Geological Survey AER/AGS Special Report 112, p. 278-289, accessed January 18, 2020, at https://ags.aer.ca/publications/SPE_112.html.

Voigt, W., 1928, Lehrbuch der kristallphysik [Textbook of crystal optics]: Vieweg+Teubner Verlag, 978 p.

Yong, A., Thompson, E.M., Wald, D., Knudsen, K.L., Odum, J.K., Stephenson, W.J., and Haefner, S., 2016, Compilation of VS30 data for the United States: U.S. Geological Survey Data Series 978, 8 p., accessed June 28, 2017, at https://doi.org/10.3133/ds978.

Zimmer, M.A., 2003, Seismic velocities in unconsolidated sands-Measurements of pressure, sorting, and compaction effects: Stanford, Calif., Stanford University, Ph.D. dissertation, $204 \mathrm{p}$. 


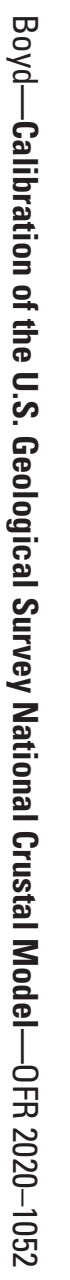

